\title{
Discovery of plasma protein biomarkers related to Alzheimer's disease, sex and APOE genotype.
}

Scott B. Laffoon ${ }^{1,2,3}$, James D. Doecke ${ }^{4}$, Anne M. Roberts ${ }^{1,3}$, Jennifer A. Vance ${ }^{5}$, Benjamin D. Reeves $^{2}$, Kelly K. Pertile ${ }^{1}$, Rebecca L. Rumble ${ }^{1}$, Chris J. Fowler ${ }^{1}$, Brett Trounson ${ }^{1}$, David Ames ${ }^{1}$, Ralph Martins ${ }^{3,6,7}$, Ashley I. Bush ${ }^{1,3}$, Colin L. Masters ${ }^{1,3}$, Paul A. Grieco ${ }^{2}$,Edward A. Dratz ${ }^{2}$, Blaine R. Roberts ${ }^{1,2,3,8^{*}}$

${ }^{1}$ Florey Institute of Neuroscience and Mental Health and The University of Melbourne Dementia Research Centre, Parkville, Victoria 3010 Australia

${ }^{2}$ Department of Chemistry and Biochemistry, Montana State University, Bozeman, MT 59715 USA

${ }^{3}$ Cooperative Research Centre for Mental Health, Carlton South, VIC, Australia.

${ }^{4}$ Australian e-Health Research Centre, CSIRO and Cooperative Research Centre of Mental health, Royal Brisbane and Women's Hospital, Brisbane, QLD, 4029, Australia

${ }^{5}$ AIT Bioscience, 7840 Innovation Blvd., Indianapolis, IN 46278, USA

${ }^{6}$ School of Medical Sciences, Edith Cowan University, Joondalup, WA, Australia.

${ }^{7}$ Department of Biomedical Sciences, Macquarie University, Norht Ryde, NSW, Australia.

${ }^{8}$ Department of Biochemistry, Department of Neurology, Emory School of Medicine, Atlanta, GA 30322 USA

*Corresponding Author: Blaine R. Roberts

Department of Biochemistry

Department of Neurology

Emory University School of Medicine

4001 Rollins Research building

Atlanta, GA 30322 USA

E-mail: blaine.roberts@emory.edu

Ph: +(404) 727-6007

Authors email addresses; 
medRxiv preprint doi: https://doi.org/10.1101/2020.04.15.20066647; this version posted April 18, 2020. The copyright holder for this preprint (which was not certified by peer review) is the author/funder, who has granted medRxiv a license to display the preprint in perpetuity.

\section{Abstract (242 words)}

3 The Australian Imaging and Biomarker Lifestyle (AIBL) study of aging is designed to aid the 4 discovery of biomarkers. The current study aimed to discover differentially expressed plasma 5 proteins that could yield a blood-based screening tool for Alzheimer's disease. To search for 6 biomarkers and elucidate mechanisms of $\mathrm{AD}$, we immuno-depleted the most abundant plasma 7 proteins and pre-fractionated the remaining proteins by HPLC, prior to two-dimensional gel 8 electrophoresis. The relative levels of approximately 3,400 protein species resolved on the 2D 9 gels were compared using in-gel differential analysis with spectrally resolved fluorescent protein 10 detection dyes (Zdyes ${ }^{\mathrm{TM}}$ ). Here we report on analysis of pooled plasma samples from an initial 11 screen of a sex-matched cohort of 72 probable $\mathrm{AD}$ patients and 72 healthy controls from the 12 baseline time point of AIBL. We report significant changes in variants of apolipoprotein $\mathrm{E}$, 13 haptoglobin, $\alpha 1$ anti-trypsin, inter- $\alpha$ trypsin inhibitor, histidine-rich glycoprotein, and a protein

14 of unknown identity. $\alpha 1$ anti-trypsin and $\alpha 1$ anti-chymotrypsin demonstrated plasma 15 concentrations that were dependent on $A P O E \& 4$ allele dose. Our analysis also identified an association with the level of Vitamin D binding protein fragments and complement factor I with

17 sex. We then conducted a validation study on individual samples using a targeted LC-MS/MS

18 assay. This study indicates that a peripheral protein signature has potential to aid in the

19 characterization of AD. We also found significant associations of protein levels with APOE

20 genotype, indicating that differences in genotype influence the circulating abundances of proteins 21 other than ApoE.

22 Keywords: Proteomics, 2D-PAGE, Alzheimer's disease, biomarkers, plasma, APOE, Zdye,

23 blood 
medRxiv preprint doi: https://doi.org/10.1101/2020.04.15.20066647; this version posted April 18, 2020. The copyright holder for this preprint (which was not certified by peer review) is the author/funder, who has granted medRxiv a license to display the preprint in perpetuity.

\section{$1 \quad$ Introduction (681 words)}

Alzheimer's disease (AD) is the most common cause of dementia, accounting for $60-80 \%$

3 of cases. It is estimated that there are over 40 million people suffering from AD dementia, with

4 the number expected to rise to over 100 million by the year 2050 (1). More than $75 \%$ of those

5 afflicted with dementia remain undiagnosed (2). While a small portion of AD cases are familial,

$695 \%$ of $\mathrm{AD}$ cases are late onset or "sporadic", being of unknown and possibly heterogeneous

7 etiology (3).

8 Currently, the diagnosis of AD is made by clinical assessments of cognitive impairment,

9 with the exclusion of diagnosis for other dementias. With the addition of brain imaging

10 techniques, the accuracy of diagnosis is approximately 90\% (4). The gold standard for the pre-

11 mortem diagnosis of AD involves positron emission tomography (PET) imaging of amyloid load

12 in the brain (5). Due to the expense, low availability, and the technically challenging nature of

13 PET imaging it is not suitable for population screening and there is a large research effort to

14 develop a peripheral screening tool that can be used to detect those at risk of developing AD.

15 Investigations of cerebrospinal fluid (CSF) biomarkers are proving to be effective for early

16 detection of $\mathrm{AD}$ risk(6,7). However, the collection of CSF is not a widespread practice, as it

17 requires an invasive lumbar puncture, as compared with much less-invasive blood tests. This

18 situation has led to an intensive search for blood based biomarkers that may reflect changes in

$19 \mathrm{AD}$ that are systemic, or due to either the disruption of the blood-brain barrier $(\mathrm{BBB})(8,9)$ or the

20 trafficking of proteins between the brain and blood(10). While $\mathrm{AD}$ is conceptually a brain

21 disease, there is evidence of altered protein expression in the periphery. This has been shown in

22 several avenues of research, including AD related morphological, chemical and proteomic

23 changes in red-blood cells (11-14), alterations of motility in white blood cells and changes in 
medRxiv preprint doi: https://doi.org/10.1101/2020.04.15.20066647; this version posted April 18, 2020. The copyright holder for this preprint (which was not certified by peer review) is the author/funder, who has granted medRxiv a license to display the preprint in perpetuity.

All rights reserved. No reuse allowed without permission.

1 membrane fluidity in leukocytes (15-17), as well as reports of plasma biomarker panels (18-25).

2 Previous proteomics studies have detected significant changes in proteins found in plasma,

3 serum and CSF in AD. However, none of these studies have yielded accurate, specific and

4 reproducible diagnostic markers for $\mathrm{AD}$ (26-29). This remains a significant challenge in the

5 field, but there are indications that a blood-biomarker is possible as indicated by recent reports

6 measuring the amyloid beta 40/42 ratio and tau (30-34).

Global discovery investigations of CSF and plasma proteins face an imposing dynamic

8 range of analyte concentrations, spanning approximately 10 orders of magnitude $(35,36)$,

9 whereas the various platforms for proteomic analysis of intact proteins are limited to the most

10 abundant 3-5 orders of magnitude. With the immense heterogeneity of the immunoglobulins,

11 plasma comprises many tens of thousands of protein species, of which approximately $50 \%$ by

12 weight is serum albumin (37) and $92 \%$ of the plasma protein is composed of 14 of the most

13 abundant proteins (38). Strategies that target the abundant species for removal are designed to

14 bring less abundant proteins into the three to five logs of analytical purview. Reverse phase high-

15 pressure liquid chromatography (RP-HPLC) provides a means for fractionating these species into

16 simpler subsets of proteins. The study presented here combines immuno-depletion of abundant

17 proteins from plasma, followed by RP-HPLC fractionation, and subsequent two-dimensional gel

18 electrophoresis (2DGE). The advantage that 2DGE has as a proteomic platform is its ability to

19 detect changes in a very wide range of post translationally modified protein isoforms. We also

20 employed a pooling strategy to incorporate a larger population in the study to reduce effects of

21 individual variability and to emphasize changes that are related to disease $(39,40)$. Using recently

22 developed Zdyes $(41,42)$ for covalent labeling and differential in-gel comparison of AD and

23 control plasma proteins, we conducted a proteomic screen of protein isoforms in samples obtain 
medRxiv preprint doi: https://doi.org/10.1101/2020.04.15.20066647; this version posted April 18, 2020. The copyright holder for this preprint (which was not certified by peer review) is the author/funder, who has granted medRxiv a license to display the preprint in perpetuity.

All rights reserved. No reuse allowed without permission.

1 from the Australian imaging and biomarker lifestyle study of ageing (AIBL). We have confirmed

2 several previously observed findings $(23,24)$ and report additional plasma protein signatures of

3 AD that vary with APOE $\varepsilon 4$ gene dose and sex. Finally, we attempt to validate the discovered

4 targets in individuals on a mass spectrometry based platform.

$5 \quad$ Methods and Materials (964 words)

6 Diagnosis of subjects. The Australian Imaging and Biomarker, Lifestyle (AIBL) study

7 is a dual-site, longitudinal cohort study that integrates neuroimaging, biomarker,

8 neuropsychometric and lifestyle(43). The cohort was divided into three groups; cognitively

9 healthy individuals (healthy controls, HC), and participants diagnosed with AD as defined by

10 NINCDS-ADRDA criteria (44) and confirmed by amyloid PET. APOE genotypes were

11 determined as previously described (Hixson and Vernier, 1990). Participant recruitment, cohort

12 design and clinical assessments were previously described (Ellis et al., 2009). Due to constraints

13 in sample throughput we pooled samples from each diagnostic category, the demographic and

14 biometric compositions of these pooled group of samples are shown in Table 1. The

15 demographics and biometric composition of the samples used for the validation of the markers

16 discovered in the pooled samples are provided in Table 3. Ethical approval for this study was

17 provided by The University of Melbourne Human Research Ethics Committee.

18 Plasma collection. Plasma was isolated from $15 \mathrm{~mL}$ of whole blood collected in two

19 Sarstedt s-monovette ethylenediaminetetraacetic acid (EDTA) K3E (01.1605.008) 7.5 mL tubes

20 with prostaglandin E1 (PGE1) (Sapphire Biosciences, $33.3 \mathrm{ng} / \mathrm{mL}$ ) pre-added to the tube (stored

21 at $4{ }^{\circ} \mathrm{C}$ prior to use). After whole blood was collected from overnight fasted participants by

22 venipuncture it was inverted several times and incubated on a laboratory orbital shaker for

23 approximately 15 minutes at room temperature prior to plasma preparation. The whole blood 
medRxiv preprint doi: https://doi.org/10.1101/2020.04.15.20066647; this version posted April 18, 2020. The copyright holder for this preprint (which was not certified by peer review) is the author/funder, who has granted medRxiv a license to display the preprint in perpetuity.

All rights reserved. No reuse allowed without permission.

1 was then combined into $15 \mathrm{~mL}$ polypropylene tubes and spun at $200 \mathrm{x}$ g at $20^{\circ} \mathrm{C}$ for 10 minutes

2 with no brake. Supernatant (platelet rich plasma) was carefully transferred to a fresh $15 \mathrm{~mL}$

3 tube, leaving a $5 \mathrm{~mm}$ margin at the interface to ensure the buffy coat was not disturbed. The

4 platelet rich plasma was spun at $800 \mathrm{~g}$ at $20^{\circ} \mathrm{C}$ for 15 minutes with the brake on. The platelet

5 depleted plasma was then aliquoted into $1 \mathrm{~mL}$ Nunc cryobank polypropylene tubes (Thermo

6 Scientific, USA) in $0.25 \mathrm{~mL}$ aliquots and transferred immediately to a rack on dry ice and

$7 \quad$ transferred to liquid nitrogen vapor tanks $\left(-178^{\circ} \mathrm{C}\right)$ until required for the assays.

Immuno-depletion and fractionation. The plasma from 12 individuals, selected to be

9 pooled together based on sex and disease status (Figure 1), were thawed on ice for 1 hour. The

10 plasma was centrifuged at $16,500 \mathrm{x}$ g for 2 minutes and $50 \mu \mathrm{l}$ from each individual was mixed

11 together to generate the final pooled samples. Three independent pools of EDTA plasma were

12 prepared from 12 subjects for each of male $\mathrm{AD}$ (mAD), female $\mathrm{AD}$ (fAD), male healthy control

13 (mHC) and female healthy control (fHC) groups. Pooled plasma samples were immuno-depleted,

14 using a multiple affinity removal system (MARS) 14 column according to manufacturers'

15 instructions (MARS-14, 4.6 x 100mm, Agilent), as described in the supplementary material. The

16 flow-through, low abundance proteins were collected in $15 \mathrm{~mL}$ conical vials containing $0.82 \mathrm{~g}$

17 urea (SigmaUltra) and $23 \mu 1$ glacial acetic acid (EMD Chemicals), for a final concentration of

$186 \mathrm{M}$ urea and $1 \%$ acetic acid. After complete mixing, the low abundant protein fractions were

19 frozen and stored at $-80^{\circ} \mathrm{C}$ until reverse-phase (RP) fractionation. The low abundant material

20 was further fractionated into six sub-fractions, using a C18 column (Agilent high-recovery

21 macro-porous $4.6 \mathrm{~mm} \times 50 \mathrm{~mm}$ ) operated at $80{ }^{\circ} \mathrm{C}$ (see supplemental material for details).

22 Fractions were lyophilized and re-suspended for labeling, with two spectrally resolved

23 fluorescent dyes (Zdye LLC, green emitting BDR-I-227 and blue emitting JAV-I-187). Both 
medRxiv preprint doi: https://doi.org/10.1101/2020.04.15.20066647; this version posted April 18, 2020. The copyright holder for this preprint (which was not certified by peer review) is the author/funder, who has granted medRxiv a license to display the preprint in perpetuity.

All rights reserved. No reuse allowed without permission.

1 fluorescently labelled samples were mixed and first resolved by isoelectric focusing (IEF) on 24 cm pH 3-11 Immobiline ${ }^{\mathrm{TM}}$ Drystrips (GE Healthcare) and then electrophoresed on 11\% SDS-

3 PAGE gels in the second dimension. Gels were scanned for fluorescence, using a Typhoon ${ }^{\mathrm{TM}}$

4 Trio scanner (GE Healthcare), and false-color images were produced with ImageQuant software

5 (GE Healthcare). Gel image files were imported into Progenesis SameSpots software (Nonlinear

6 Dynamics) for processing, alignment and differential analysis of the relative amounts of protein

7 species in $\mathrm{AD}$ and control pools, after normalizing spot volume intensities by the total spot

8 volume intensity in each image

10 Figure 1. Study design and experimental workflow. (1) Shows how the control and Alzheimer's 11 disease plasma was pooled into sex specific and disease specific groups. Each pooled group was 12 generated from 12 individuals. (2) The pooled plasma was then depleted of the 14 most abundant 13 proteins using the multiple affinity removal system (MARS14, Agilent Tech.). The low 14 abundance proteins were further fractionated using reverse phase chromatography (3) to generate 156 fractions (4) for 2D differential gel electrophoresis of proteins labeled with Zdyes ${ }^{\mathrm{TM}}(4)$. Spot volumes were considered significantly changed if there was greater than a 1.3-fold 17 change between groups and a $\mathrm{p}<0.05$ with a false discovery rate of 0.05 calculated as described 18 in Storey et al. (45), when comparing the six pools $(\mathrm{N}=12$ per pool) of $\mathrm{AD}$ subjects with six 19 pools of healthy controls (HC). Additionally, protein spots were compared within male and

20 female pools between $\mathrm{AD}$ and $\mathrm{HC}$ groups (three pools each for each sex). When comparing 21 differences between the sexes, a cut-off of greater than 1.7-fold change in protein levels was 22 applied. Spearman's rank correlation and linear regression was used to investigate the 23 relationship between the number of APOE alleles and ApoE protein quantity. 
medRxiv preprint doi: https://doi.org/10.1101/2020.04.15.20066647; this version posted April 18, 2020. The copyright holder for this preprint (which was not certified by peer review) is the author/funder, who has granted medRxiv a license to display the preprint in perpetuity.

All rights reserved. No reuse allowed without permission.

Identification of proteins-of-interest. To identify changing protein variants, spots-ofinterest were excised manually from analytical or preparative gels of fractionated proteins, for in-

3 gel digestion with proteomics grade porcine trypsin (Sigma-Aldrich, Castle Hill, Australia),

4 following previously published methods for in-gel digestion (46). Mass spectrometry data

5 [obtained as described in the supplementary material] were used to search the Swiss-Prot Homo

6 sapiens database, using MASCOT version 2.4.1 (Matrix Science). Fixed modification of

7 carbamidomethylation of cysteine, and variable modifications including oxidation of methionine,

8 deamidation of asparagine and glutamine, and a single missed cleavage were allowed for the

9 protein searches, using $2+$ and $3+$ peptide charge states.

Selected reaction monitoring QQQ mass spectrometry. Peptides were selected and

11 synthesized, with heavy isotope labeling, for 76 protein targets by MRM-Proteomics (BAK76-

12 kit, Canada). Samples were processed using the manufacturer's protocol (additional details in

13 supplemental materials). The liquid chromatography mass spectrometry was conducted on with

14 a 1290 UHPLC coupled to a 6495 QQQ mass spectrometer (Agilent Technologies, Mulgrave, 15 VIC).

16 Statistical analyses were conducted using: Progenesis QI (Waters, UK) for the 2D gel

17 data; GraphPad Prism v 8.0 for Mac OS X (GraphPad Software, USA) for the ROC; t-test

18 analysis: One-way ANOVA with Sidak correction of multiple comparisons and Chi-squared test.

19 A p-value $<0.05$ was considered significant.

20 Results (1518 words)

21 Demographic details are listed in Table 1. The AD cohort was significantly older by 9.8 years

22 (AD group $79.6 \pm 3.1$ years, $\mathrm{HC}$ group $69.8 \pm 3.2$ years, $\mathrm{p}=0.0001$ ) and the AD population was

23 significantly enriched in the APOE $\varepsilon 4$ allele $(40 \%, \mathrm{AD} ; 13 \%, \mathrm{HC} ; \mathrm{p}=0.0001)$ as anticipated 
medRxiv preprint doi: https://doi.org/10.1101/2020.04.15.20066647; this version posted April 18, 2020. The copyright holder for this preprint (which was not certified by peer review) is the author/funder, who has granted medRxiv a license to display the preprint in perpetuity.

All rights reserved. No reuse allowed without permission.

1 (47). Body mass index (BMI) data were available for 54/72 AD subjects and 60/72 HC subjects.

2 Using the available data showed a trend $(\mathrm{p}=0.06)$ of somewhat lower BMI in AD pools $(24.9 \pm$

$\left.31.4 \mathrm{~kg} / \mathrm{m}^{2}\right)$ than HC pools $\left(26.5 \pm 1.1 \mathrm{~kg} / \mathrm{m}^{2}\right)$. All of the controls had an amyloid PET scan

4 confirming the lack of significant brain amyloid accumulation and approximately half of 56/72

5 of the AD cases had a corresponding PET, which confirmed the AD diagnosis. An extensive

6 analysis of the PET data collected on this cohort can be found in Pike et al. (2007) (48).

7 Discovery $2 \mathrm{D}$ gel investigation of human plasma. The immuno-depletion and RP-HPLC

8 fractionation strategy produced six fractions (F1-6) of proteins for comparison by 2DGE (Figure

9 1). Representative analytical gel images of each of the six RP fractions are shown in Figure 2.

10 Approximately 3,400 unique protein species were analyzed by this method after reducing the

11 total spot count by $10 \%$, to correct for proteins estimated that eluted in more than one fraction.

12 The inclusion of RP-HPLC fractionation resulted in a roughly linear 6x increase in the quantity

13 of protein spots measured. The increase was attributed to resolution of proteins that co-migrate

14 on 2DGE which have different hydrophobic characters and are thus separated by RP-HPLC,

15 reducing interference in the analysis of gels. In addition, RP-HPLC enriches proteins, allowing

16 lower abundance species to be appear with stronger fluorescent signals on the $2 \mathrm{D}$ gels.

Figure 2. Representative $2 \mathrm{D}$ gel images from the six RP fractions. The arrows indicate the

19 protein spots with abundance changes in $\mathrm{AD}$ pools compared to $\mathrm{HC}$, as discussed in the Results 20 and Discussion sections.

Spots that met the inclusion criteria for significant differences $(>1.3$ fold, adjusted $\mathrm{p}$ 23 value $<0.05)$, as described above, are indicated by the arrows in Figure 2 and listed in Table 2. 
medRxiv preprint doi: https://doi.org/10.1101/2020.04.15.20066647; this version posted April 18, 2020. The copyright holder for this preprint (which was not certified by peer review) is the author/funder, who has granted medRxiv a license to display the preprint in perpetuity.

All rights reserved. No reuse allowed without permission.

1 Isoform variants, subunits or cleavage products of eight proteins that discriminated AD from

2 control, according to the inclusion criteria, were identified: zinc $\alpha$ 2-glycoprotein (ZAG),

3 histidine-rich glycoprotein (HRG) fragment, haptoglobin (Hpt), vitamin D binding protein

4 (VDBP), complement factor I (CFI), inter- $\alpha$ trypsin inhibitor (ITHI), $\alpha-1$ anti-trypsin ( $\alpha 1 \mathrm{AT})$ and

5 apolipoprotein E (ApoE). One significant spot in fraction \#1 (F1) was unidentified. Features of

6 proteins that showed significant abundance changes are as follows:

Zinc $\alpha$ 2-glycoprotein. Two putative glycoforms of zinc $\alpha$ 2-glycoprotein (ZAG, Figure 2

8 F1, arrows a and b) showed significant increase in abundance in the AD pools $(1.9$-fold, $\mathrm{p}<0.05$

9 and 1.5-fold, $\mathrm{p}<0.05$ respectively, Table 2). An adjacent isoform (Figure $2 \mathrm{~F} 1$, arrow c) also

10 showed a trend towards being increased in $\mathrm{AD}$ pools although it did not quite meet statistical

11 significance (1.3-fold, $\mathrm{p}=0.06)$.

Haptoglobin. Haptoglobin (Hpt) is an abundant, acute phase response (APR) polymeric

13 glycoprotein that is synthesized in the liver and is composed of varied combinations of four

14 disulfide linked chains (two $\alpha^{1}$ chains of $\sim 8.9 \mathrm{kDa}$ that differ by a single amino-acid substitution,

$15 \alpha^{2}$ chain $\sim 16 \mathrm{kDa}$, and $\beta$ chain $\left.\sim 45 \mathrm{kDa}\right)$. Normal human populations commonly possess

16 quaternary structural variations and heterogeneous stoichiometry of disulfide-linked Hpt chains

17 (49), potentially yielding proteins composed of identical chains with differing pIs. In the current

18 study the disulfide bridges were intact in the first 2D gel separation dimension and then reduced

19 after isoelectric focusing, so the subunits in the second dimension had the same pI patterns as the

20 intact Hpt complexes. To avoid issues arising from mis-matching of heterogeneously focused

21 spots in the comparison between pools, we quantified each of the Hpt spot-trains at $8.9 \mathrm{kDa}, 16$

$22 \mathrm{kDa}$ and $45 \mathrm{kDa}$ (Figure $2 \mathrm{~F} 2$, arrows $\mathrm{d}$, e, and $\mathrm{f}$ respectively) as the summed value of the

23 respective constituent isoforms. Two haptoglobin (Hpt) chains ( $\beta$ chain $\sim 45 \mathrm{kDa}$ - Figure 2 F2, 
medRxiv preprint doi: https://doi.org/10.1101/2020.04.15.20066647; this version posted April 18, 2020. The copyright holder for this preprint (which was not certified by peer review) is the author/funder, who has granted medRxiv a license to display the preprint in perpetuity.

1 arrow $\mathrm{d}$ and $\alpha^{1}$ chain $\sim 8.9 \mathrm{kDa}$ - Figure $2 \mathrm{~F} 2$, arrow e) were significantly higher in $\mathrm{AD}$ pools

2 (2.0-fold, $\mathrm{p}<0.01$ and 2.4-fold, $\mathrm{p}<0.02$ respectively, Table 2). No significant difference was

3 found in Hpt $\alpha^{2}$ chain (Figure 2 F2, arrow f). False-color image overlays of the F2 gels,

4 qualitatively representing changes in Hpt species, are shown in Figure 3, where the ovals in the

5 upper right image indicate the three different subunit spot trains.

7 Figure 3. False-color image overlays of F2 two-color multiplex gels prior to spot-matching

8 alignment. Three subunit chains of Hpt are outlined in ovals in the upper right image. The AD

9 pools are represented by green in the upper three images and by red in the lower images,

10 reflecting the dye labeling reversals. Yellow represents approximately equal contribution of

11 intensity from $\mathrm{AD}$ and control proteins.

Inter- $\alpha$ trypsin inhibitor. Two cleavage products of inter- $\alpha$ trypsin inhibitor (ITIH) heavy

14 chain were significantly higher in AD pools. A 12-15 kDa C-terminal cleavage product (Figure 2

$15 \mathrm{~F} 3$, arrow g) and an approximately $40 \mathrm{kDa}$-terminal cleavage product (Figure $2 \mathrm{~F} 4$, arrow $\mathrm{h}$ )

16 were both increased 1.3 fold in $\mathrm{AD}$ pools $(\mathrm{p}<0.05$ and $\mathrm{p}<0.02$ respectively, Table 2 ).

17 Apolipoprotein E. The most chemically basic protein spot of the apolipoprotein E (ApoE)

18 spot train (Figure 2 F5, arrow i) was significantly higher in the AD pools $(1.5$ fold, $\mathrm{p}<0.02$,

19 Table 2). The $34 \mathrm{kDa}$ ApoE spot train results from the superposition of the protein products of

20 the APOE $\varepsilon 2, \varepsilon 3$ and $\varepsilon 4$ alleles carried by the individuals contributing to the pools. Each of the

21 alleles produces three clearly visible protein spot clusters, likely due to heterogeneous

22 deamidations and glycosylations (50). The substitution of an arginine for a cysteine in ApoE $\varepsilon 4$

23 (C112R), results in a shift of its isoelectric point (pI) toward the cathode, basic (right shift) 
1 relative to the ApoE \&3 position. Additionally, plasma proteins are subject to non-enzymatic

2 deamidation in vivo, a process that adds negative charges (51), creating features of the horizontal

3 spot trains by shifting species discretely toward the anode, leftward on gels. The partially

4 overlapping superposition of ApoE $\varepsilon 3$ with $\varepsilon 4$ variants appeared as four clusters of spots in most

5 of the pooled samples, with the most chemically basic cluster comprising only ApoE $\varepsilon 4$ variants.

6 Therefore, the most basic cluster of ApoE spots provides a protein isoform proxy for the relative

7 amounts of APOE $\varepsilon 4$ allele within the pools. Figure $4 \mathrm{~A}$ shows strong Pearson correlation $\left(\mathrm{R}^{2}=\right.$

$80.82, \mathrm{p}<0.0001)$ of the normalized spot intensity of the most basic ApoE " $\varepsilon 4$ proxy" variant,

9 with the averaged gene dosage of the APOE $\varepsilon 4$ allele in the pools of this study.

F6 gels exhibited a series (Figure 2 F6, arrow j) comprising six to seven variants of the

11 same apparent molecular weight $(\sim 35 \mathrm{kDa})$ as the F5 ApoE series. However, none of the F6

12 ApoE variants significantly correlated with APOE genotype.

$13 \alpha-1$ Anti-trypsin. A circulating species of $\alpha-1$ anti-trypsin $(\alpha 1 \mathrm{AT})$ that was not bound by

14 the immuno-depletion column (Figure 2 F5, arrow k) was significantly higher in AD pools (3.3

15 fold, $\mathrm{p}<0.02$, Table 2 ). The $\alpha 1 \mathrm{AT}$ variant also closely correlated in regression analysis with the

$16 \varepsilon 4$ proxy spot volumes (Figure $4 \mathrm{~B}, \mathrm{R}^{2}=0.83, \mathrm{P}<0.0001$ ). The $\alpha 1 \mathrm{AT}$ variant that correlated with

17 the $\varepsilon 4$ proxy spot is shown in Figure 4D, where the $i$ panel has low $\varepsilon 4$ proxy and the $i i$ panel has

18 high $\& 4$ proxy. The relationship of these spots is qualitatively represented in the false-color image

19 overlay in Figure 4C, indicated by white arrows.

21 Figure 4. A. Regression analysis of the basic F5 ApoE variant ( $\& 4$ proxy) with the fractional

$22 A P O E \& 4$ gene dosage of the 12 pools: $\mathrm{R}^{2}=0.83, \mathrm{p}<0.0001$. Pool symbols are male healthy

23 controls $-\times$, female healthy controls $-\Delta$, male AD $-\square$, female $\mathrm{AD}-\diamond$. B. Regression analysis of 
1 total cohort, non-binding $\alpha 1$-antitrypsin $(\alpha 1 \mathrm{AT})$ variant vs. apoE $\varepsilon 4$ proxy: $\mathrm{R}^{2}=0.82, \mathrm{p}<0.0001$;

2 Pools are $\mathrm{n}=12$. Group symbols are: $\mathrm{AD}-$ ?, $\mathrm{HC}-+$. C. F5 multiplex gels that have not been

3 aligned for spot-matching. Arrows indicate the correlated changes between the $\varepsilon 4$ proxy spot

4 (lower end) and the AD significant $\alpha 1 \mathrm{AT}$ variant (upper end). The AD pools are represented by

5 red in the upper three images and by green in the lower images, reflecting the dye reversal.

6 Yellow represents approximately equal contribution of intensity from AD and control proteins.

7 D. Detail from a pair of multiplexed gel images representative of low ApoE $\varepsilon 4$ containing pools

8 (panel $i$ ) and high ApoE $\& 4$ containing pools (panel $i i$ ). The level of $\alpha 1 \mathrm{ACT}$ isoforms correlated

9 with the $34 \mathrm{kDa} A p o E \varepsilon 4$ proxy spot that is shown in lower right-hand corners of the panel $i$ and

10 ii images. Regression analysis Pearson correlations: $\mathrm{a}-\mathrm{p}=0.012, \mathrm{R}^{2}=0.45 ; \mathrm{b}-\mathrm{p}=0.002, \mathrm{R}^{2}=0.61$;

$11 \mathrm{c}-\mathrm{p}=0.003, \mathrm{R}^{2}=0.56 ; \mathrm{d}-\mathrm{p}=0.002, \mathrm{R}^{2}=0.61 ; \mathrm{e}-\mathrm{p}=0.007, \mathrm{R}^{2}=0.51 ; \mathrm{f}-\mathrm{p}=0.003, \mathrm{R}^{2}=0.58$. None of

12 the $\alpha 1 \mathrm{ACT}$ spots significantly discriminated the AD group from the HC group. The $\alpha 1 \mathrm{AT}$ spot

13 that significantly discriminated $\mathrm{AD}$ from $\mathrm{HC}$ pools $(3.3$ fold, $\mathrm{p}<0.02$,) is shown in panel $i i$.

An unidentified protein spot (Figure 2 F1, arrow 1) was significantly lower $(1.5$-fold, $\mathrm{p}<$ 0.05, Table 2) in $\mathrm{AD}$ pools.

17 Sex specific differences. Vitamin D binding protein (VDBP) cleavage product isoforms,

18 (Figure 1 F3, arrows $\mathrm{n}, \mathrm{o}, \mathrm{x}$ and Figure 5, demonstrated asymmetric sex-dependent $\mathrm{AD}$

19 associations. In female AD pools, several cleavage products of VDBP were in significantly

20 higher concentrations relative to female control pools $(\mathrm{p}<0.05)$. In male AD pools, many of the

21 same VDBP cleavage products had significantly lower concentrations, relative to male control 22 pools $(\mathrm{p}<0.05$, Figure 5). 
medRxiv preprint doi: https://doi.org/10.1101/2020.04.15.20066647; this version posted April 18, 2020. The copyright holder for this preprint (which was not certified by peer review) is the author/funder, who has granted medRxiv a license to display the preprint in perpetuity.

All rights reserved. No reuse allowed without permission.

$1 \quad$ Figure 5. Intact and cleaved VDBP with sex specific changes shown in tables on the right. A.

2 Intact (top spot train) and cleaved VDBP (spots $\mathrm{A}, \mathrm{B}, \mathrm{C}$ ). This spot train corresponds to $\mathrm{n}$ in

3 Figure 2 F3. The intact VDBP spots were saturated and masked from the Progenesis analysis. B.

4 Cleaved VDBP (A - M). This cluster of cleavages corresponds to o in Figure 2 F3. C. Cleaved

$5 \operatorname{VDBP}(\mathrm{A}-\mathrm{E})$. This cluster of cleavages corresponds to $\mathrm{x}$ in Figure 2 F3. Significant changes (p

$6<0.05)$ are shown in bold.

Isoforms of complement factor I (Figure 2 F3 arrows p, q, r, s) also showed significant

9 asymmetrical sex-specific dysregulation in AD (Table 2).

10 Targeted Validation of 2D gel biomarkers. The discovery experiment conducted with 2D

11 gels had several limitations, including the use of pooled plasma, which limits the ability to

12 determine the potential for these markers to provide meaningful discriminatory signals in

13 individuals. To validate the differentially expressed proteins in individual samples, we used a

14 multiplexed quantitative LC-MS/MS assay developed by MRM proteomics (BAK76, Canada).

15 Plasma (Li heparin) samples were obtained from AIBL (Demographics Table 3) and included an

16 even number of males and females and cognitively normal controls $(n=44)$ and probable AD

$17(n=44)$. We could not confirm the elevation of any of the eight proteins we discovered using the

18 pooled samples (Figure 6). However, we did discover that complement C3, beta-2-microglobulin

19 and peroxiredoxin-2, proteins, previously reported to be changed in the literature $(29,52-54)$,

20 were elevated in AD plasma (Figure 6). We did not replicate any of the associations we observed

21 with sex or genotype in the discovery experiment ( $\mathrm{p}>0.05$, one-way ANOVA). However, this

22 likely to be due to the inability to distinguish the several proteoforms that were observed by $2 \mathrm{D}$

23 gels with an assay that measures total abundance of all the proteoforms of a protein. Receiver 
medRxiv preprint doi: https://doi.org/10.1101/2020.04.15.20066647; this version posted April 18, 2020. The copyright holder for this preprint (which was not certified by peer review) is the author/funder, who has granted medRxiv a license to display the preprint in perpetuity.

All rights reserved. No reuse allowed without permission.

1 operating characteristic (ROC) analysis for complement C3, beta-2-microglobulin and

2 peroxiredoxin 2 indicate that they only have weak discriminatory (accuracy ranged between 60-

$365 \%$ ) ability to distinguish between cognitively normal from AD (Table 4).

4

5 Figure 6. Measurement of plasma biomarkers in control ( $n=44$, black diamonds) and

6 Alzheimer's disease ( $n=44$, grey circles) plasma. Biomarker candidates discovered using 2D gels

7 were targeted and measured using LC-MS/MS and heavy labeled $\left(\left[{ }^{13} \mathrm{C}_{6},{ }^{15} \mathrm{~N}_{2}\right.\right.$-lysine $]$ or $\left[{ }^{13} \mathrm{C}_{6}\right.$

$8,{ }^{15} \mathrm{~N}_{4}$-arginine) peptides as internal standards. P-values were calculated using a one-way

9 ANOVA and Sidak correction for multiple comparisons.(94)

\section{Discussion (1596 words)}

12 The effect of the APOE genotype on protein expression is an important consideration for

13 the refinement of discovery and validation of future biomarkers in plasma (55). Consistent with

14 this found significant correlation of increasing $\alpha 1$-antitrypsin $(\alpha 1 \mathrm{AT})$ with APOE $\varepsilon 4$ genotype in

15 plasma. We also found increased levels of cleavage products of VDBP in females with AD and a

16 decrease in the cleavage products in males with AD. (Figure 5). Due to the enrichment of APOE

$17 \varepsilon 4$ genotype in $\mathrm{AD}$ cohorts, studies that compare controls vs $\mathrm{AD}$ are also confounding

18 populations of $20 \%$ APOE $\varepsilon 4$ positive versus an AD population with $40-80 \%$ APOE $\varepsilon 4$ positive.

19 To the best of our knowledge the current study is the first plasma proteomics study indicating

20 that $\alpha 1 \mathrm{AT}$ or $\alpha 1$ anti-chymotrypsin $(\alpha 1 \mathrm{ACT})$ have correlations with the APOE.

$21 \alpha-1$ Anti-trypsin ( $\alpha 1 \mathrm{AT})$ is an abundant, circulating, acute phase response (APR) serine

22 protease inhibitor (serpin) that was targeted for removal from the analyte proteins by immuno-

23 depletion (Figure 1 MARS14). The close correlation of $\alpha 1$ AT with the $\varepsilon 4$ proxy variant, shown 
medRxiv preprint doi: https://doi.org/10.1101/2020.04.15.20066647; this version posted April 18, 2020. The copyright holder for this preprint (which was not certified by peer review) is the author/funder, who has granted medRxiv a license to display the preprint in perpetuity.

All rights reserved. No reuse allowed without permission.

1 in Figure 4B, suggests that $\alpha 1 \mathrm{AT}$ may be a marker of the mode by which APOE $\varepsilon 4$ contributes to

2 the etiology of AD. It is of interest that $\alpha 1 \mathrm{AT}$, which is a serpin with known associations to AD

3 in blood (56-58), $\operatorname{CSF}(59,60)$ and senile plaques (61) also correlated with the APOE $\varepsilon 4$ allele

4 (Figure 4B), however the specific physiological role of $\alpha 1 \mathrm{AT}$ in tissues is not well elucidated.

5 The Alzgene website shows a single positive genetic association of AD with an $\alpha 1 \mathrm{AT}$ allele,

6 from a small, unconfirmed 1996 study (62). Analysis of total $\alpha 1$ AT in neat undeleted plasma

7 from individuals did not display any significant changes (Figure 6).

The APR serpin, $\alpha 1 \mathrm{ACT}$, did not significantly discriminate AD from control pools,

9 however, regression analysis of $\alpha 1 \mathrm{ACT}$ variants significantly correlated with the $\varepsilon 4$ proxy spot

10 volumes (Figure 4D). $\alpha 1$ ACT has been reported to have genetic associations with AD $(63,64)$

11 and has been found in elevated concentration in plasma $(65,66)$ and CSF (67) in AD. $\alpha 1 \mathrm{ACT}$ is

12 more highly expressed in the brains of $\mathrm{AD}$ patients and is a component of senile plaques (68), as

13 is ApoE (69). Previous studies have suggested relationships between plasma concentrations of

$14 \alpha 1 \mathrm{ACT}$ and APOE genotype, but the results have been inconsistent. A radial immunodiffusion

15 study found no correlation of APOE genotype with levels of $\alpha 1$ ACT in plasma or serum (70). An

16 enzyme linked immuno-sorption assay study, showed $\alpha 1$ ACT to have positive predictive value

17 for the rate of cognitive decline in $\varepsilon 4$ carriers, and no age-dependence, in $\mathrm{AD}$ patients (71). $\mathrm{A}$

18 nephelometric assay study showed higher concentrations of plasma $\alpha 1 \mathrm{ACT}$ in AD patients who

19 were non-APOE $\varepsilon 4$ carriers (72). Functionally, $\alpha 1 \mathrm{ACT}$ was shown to induce hippocampus and

20 cerebral cortex plaque formation in mouse models of $\mathrm{AD}(73)$, as well as the phosphorylation of

21 tau in the neurons of transgenic mice (74). Both $\alpha 1 \mathrm{ACT}$ and $\alpha 1 \mathrm{AT}$ bind $\mathrm{A} \beta$ and suppress its in

22 vitro fibrillization, which is a necessary process for the formation of senile plaques in vivo (75).

23 Thus its role in AD may be more important at the functional level then as a maker of disease. 
medRxiv preprint doi: https://doi.org/10.1101/2020.04.15.20066647; this version posted April 18, 2020. The copyright holder for this preprint (which was not certified by peer review) is the author/funder, who has granted medRxiv a license to display the preprint in perpetuity.

All rights reserved. No reuse allowed without permission.

The elevated Hpt that we observed along with other circulating APR proteins may be a

2 peripheral response to activated endothelia of the brain vessels. Various means by which cross-

3 talk between central and peripheral inflammation may occur have been summarized (76). The

4 possibility that Hpt flow-through from the immuno-depletion column enriched a sub-population

5 of non-binding conformers may be supported by the selective enrichment of $45 \mathrm{kDa}$ and $8.9 \mathrm{kDa}$

6 chains in the significantly changed species of AD pools, without a significant change of the 16

$7 \quad \mathrm{kDa}$ chain. The question of whether Hpt was significantly higher in the flow-through because it

8 exceeded the binding capacity of the column, or because of steric hindrance was beyond the

9 scope of this study. In agreement with our observation, a previous report using a MARS column

10 also observed an increase in Hpt in both $\mathrm{AD}$ and type 2 diabetes plasma (77) indicating that an

11 Hpt increase is likely due to a general increase in inflammation. When measured in individuals

12 there was no significant increase (Figure 6) in Hpt but this may be due to the inability of the LC-

13 MS/MS method used to discriminate between the 45, 16 and $8.9 \mathrm{kDa}$ chains.

14 Systemic inflammation is commonly measured clinically by assay of plasma C-reactive

15 protein (CRP) (78). Circulating CRP is primarily synthesized in the liver and, like Hpt, CRP

16 synthesis is mediated by the pro-inflammatory cytokines IL-1 $\beta$ and IL-6 (79). CRP is elevated in

17 AD brain (80), but is not consistently higher in AD plasma. In the current study, CRP was

18 detected in the 2DGE but when measured in the validation cohort by LC-MS the CRP levels

19 were sporadic and no significant elevation was observed in AD (Figure 6). The highly variable

20 nature of the CRP levels is consistent with its role in acute phase inflammation response that

21 changes with a large range of pathologies and not specific for AD.

22 Zinc $\alpha$ 2-glycoprotein (ZAG) is a $41 \mathrm{kDa}$ glycoprotein adipokine believed to function as

23 a lipid mobilizing factor (81). In a study with a relatively wide range of body mass indices 
medRxiv preprint doi: https://doi.org/10.1101/2020.04.15.20066647; this version posted April 18, 2020. The copyright holder for this preprint (which was not certified by peer review) is the author/funder, who has granted medRxiv a license to display the preprint in perpetuity.

All rights reserved. No reuse allowed without permission.

1 (BMI), serum ZAG discriminated groups with a negative correlation between BMI and ZAG

2 concentrations (82). ZAG has been found significantly lower in ventricular CSF of AD patients,

3 discriminating $\mathrm{AD}$ from normal controls and non-AD dementias (83). Lower BMI has been

4 associated with risk of $\mathrm{AD}(84)$. In the current study, BMI data were available for 54/72 AD

5 subjects and 60/72 control subjects and was significantly higher in the AD pools (Table 1),

6 consistent with elevated ZAG variants observed. The validation study on individual samples

7 showed a trend $(\mathrm{p}=0.06)$ towards elevated levels of $\mathrm{ZAG}$ in plasma from AD cases (Figure 6).

In addition to disease classification, participants were evenly pooled according to sex. A

9 consensus has yet to be reached as to the prevalence of sex-specific differences in $\operatorname{AD}(85,86)$

10 and there is limited proteomic data on plasma investigating sex specific differences between $\mathrm{AD}$

11 and controls. To look for sex-specific dysregulation of proteins, we made intra-sex comparisons

12 between $\mathrm{AD}$ and $\mathrm{HC}$ pools and found Vitamin $\mathrm{D}$ binding protein (VDBP) and Complement

13 factor I (CFI) to be differentially regulated according to sex. VDBP is an abundant, monomeric

$14 \quad 52-59 \mathrm{kDa}$ glycoprotein that functions as the primary plasma transporter of the sterol vitamin $\mathrm{D}$

15 and its metabolites (87). In addition to its role as vitamin D transporter, VDBP scavenges and

16 sequesters actin monomers in the blood after cellular damage. It does so in concert with gelsolin

17 (88), protecting micro-vasculature from the detrimental effects of ectopic actin fibrillization.

18 VDBP is a regulator of macrophages and osteoclasts, and as an important chemotactic factor for

19 leukocytes (89), independent of its vitamin D binding function. Its synthesis is estrogen

20 dependent (90) and blood concentration is significantly lower in males than females $(91,92)$. The

21 gel image of F3 shows three abundant spot-trains of cleaved VDBP species (Figure 1 F3, arrows

$22 \mathrm{n}, \mathrm{o}, \mathrm{x}$ ), below the intact VDBP spot-train (Figure $1 \mathrm{~F} 3$, arrow $\mathrm{m}$ ). The three spot-train clusters of

23 cleaved peptides focused as disulfide bound complexes in the IEF step, to similar pIs as the 
medRxiv preprint doi: https://doi.org/10.1101/2020.04.15.20066647; this version posted April 18, 2020. The copyright holder for this preprint (which was not certified by peer review) is the author/funder, who has granted medRxiv a license to display the preprint in perpetuity.

All rights reserved. No reuse allowed without permission.

1 uncleaved variants, as they were unified by 14 intra-chain disulfide bridges. After focusing,

2 chemical reduction released cleaved peptides to migrate to their respective lower apparent

3 molecular weights. The proteoform difference observed with $2 \mathrm{D}$-gels was not recapitulated with

4 the LC-MS/MS assay that measured the total pool of VDBP (Figure 6).

CFI is a complement activation inhibitor that has been shown to undergo disrupted

6 function in vitro in the presence of $\mathrm{A} \beta$ (93). CFI plasma concentration is modestly decreased in

$7 \mathrm{AD}$ and correlated with brain volume (29), but we found no reports of gender specificity.

8 Further, when measured in individuals we did not see any gender differences.

9 The etiology of AD, as for many diseases, is complex and polygenic. Pooled proteomics

10 studies are designed to detect sporadically changing disease-related isoforms that change

11 consistently enough in afflicted subjects to effect consistent "average" changes within pools, and

12 as such constitutes a limitation of the current study. Our future studies aim to validated and

13 understand the relationships between VDBP, CFI, $\alpha 1 \mathrm{ACT}$, and $\alpha 1 \mathrm{AT}$ with sex and genotype,

14 respectively. Here we measured the biomarkers discovered with 2DGE using a quantitative LC-

15 MS/MS assay and the changes we observed by 2DGE were not validated with this approach.

16 However, we did measure samples by quantitative LC-MS/MS that were independent of the

17 discovery study and differences between $\mathrm{AD}$ and control values of several of the markers

18 approached statistical significance (e.g. VDBP; Figure 6). Overall, the measurement of total

19 protein by LC-MS rather than proteoform-specific changes measured via 2DGE offers a potential

20 explanation for the failure to validate the 2DGE discoveries. However, the replication of

21 elevation of beta-2-microglobulin, complement C3 and peroxiredoxin 2 validate previous reports

22 of these changes in $\mathrm{AD}$ and of the LC-MS/MS based assay to report global protein level changes

23 (29,52-54). The correlation $\alpha 1 \mathrm{AT}$ or $\alpha 1 \mathrm{ACT}$ with the APOE genotype indicates that the point 
medRxiv preprint doi: https://doi.org/10.1101/2020.04.15.20066647; this version posted April 18, 2020. The copyright holder for this preprint (which was not certified by peer review) is the author/funder, who has granted medRxiv a license to display the preprint in perpetuity.

All rights reserved. No reuse allowed without permission.

1 mutation differences between APOE $\varepsilon 2 / 3 / 4$ may have wider impact than on the function of just

2 the ApoE protein as a recent proteomic study in AD brain tissue has demonstrated (55). Further,

3 the failure

4 to validate many of the protoeform changes highlights the inability of assays that measure the

5 total abundance of a protein target (e.g. ELISA, LC-MS/MS) to reflect the complexity of the

6 proteome. Overall, complement $\mathrm{C} 3$, beta-2-microglobulin and peroxiredoxin-2 may add value to

7 the emerging plasma amyloid b2 and tau assays for the early diagnosis of AD. 
1 Table 1. Demographic data for each group of pooled plasma ( $\mathrm{n}=12$ individuals per pool, three groups per condition). The $\mathrm{p}$-value was

2 calculated with a two-tailed Student's t-test between All AD and All controls only.

3 *BMI values from 54/72 AD subjects, 60/72 control subjects. Samples are from the baseline timepoint of the ABIL study.

4

\begin{tabular}{cccccccc}
\hline Parameter & $\begin{array}{c}\text { Female } \\
\text { AD }\end{array}$ & Male AD & $\begin{array}{c}\text { Female } \\
\text { Controls }\end{array}$ & $\begin{array}{c}\text { Male } \\
\text { Controls }\end{array}$ & All AD & All Controls & p-value \\
\hline Age in years & $82.2(1.2)$ & $77.0(1.8)$ & $69.1(1.5)$ & $70.5(4.7)$ & $79.6(3.1)$ & $69.8(3.2)$ & 0.0001 \\
$\%$ APOE $\varepsilon 4$ & $37.5(4.2)$ & $43.1(16.8)$ & $19.4(2.4)$ & $6.9(6.4)$ & $40.3(11.4)$ & $13.2(8.1)$ & 0.0001 \\
BMI $\left(\mathrm{kg} / \mathrm{mg}^{2}\right)^{*}$ & $25.2(1.2)$ & $24.6(1.7)$ & $27.2(1.7)$ & $25.9(0.3)$ & $24.9(1.4)$ & $26.5(1.3)$ & 0.06
\end{tabular}

\section{5}

$\mathrm{n}$

36

36

36

36

72

72 
1 Table 2. Differentially expressed proteins discovered with 2D gel proteomics with a p-value $<0.05$.

\begin{tabular}{|c|c|c|c|c|c|c|c|c|c|c|c|c|}
\hline \multirow[b]{2}{*}{ Protein name } & \multirow[b]{2}{*}{ Accession \# } & \multirow{2}{*}{$\begin{array}{c}\text { RP } \\
\text { Fraction } \\
\text { ID }\end{array}$} & \multirow{2}{*}{$\begin{array}{l}\text { MW } \\
\text { (kDa) }\end{array}$} & \multicolumn{2}{|c|}{ Whole cohort } & \multicolumn{2}{|c|}{ Male cohort } & \multicolumn{2}{|c|}{ Female cohort } & \multirow[b]{2}{*}{\begin{tabular}{|c|} 
MS \\
method \\
\end{tabular}} & \multirow{2}{*}{$\begin{array}{c}\text { Mascot } \\
\text { Score/ } \\
\text { \#peptides }\end{array}$} & \multirow[t]{2}{*}{ Comment } \\
\hline & & & & \begin{tabular}{|c|}
$\begin{array}{c}\text { AD fold } \\
\text { change }\end{array}$ \\
\end{tabular} & $\mathrm{p}$-value & $\begin{array}{c}\mathrm{AD} \text { fold } \\
\text { change }\end{array}$ & $\mathrm{p}$-value & $\begin{array}{c}\text { AD fold } \\
\text { change }\end{array}$ & $\mathrm{p}$-value & & & \\
\hline Zinc $\alpha$ 2-glycoprotein (ZAG) & $\mathrm{P} 25311$ & $1 \mathrm{a}$ & 40 & 1.9 up & $<0.05$ & NS & NS & NS & NS & 2 & NS & Most basic glycoform \\
\hline Zinc $\alpha$ 2-glycoprotein (ZAG) & $\mathrm{P} 25311$ & $1 \mathrm{~b}$ & 40 & 1.5 up & $<0.05$ & NS & NS & NS & NS & 2 & $111 / 4$ & Most basic glycoform \\
\hline Zinc $\alpha$ 2-glycoprotein (ZAG) & $\mathrm{P} 25311$ & $1 \mathrm{c}$ & 40 & 1.3 up & 0.06 & NS & NS & NS & NS & 2 & $88 / 6$ & NS but trending \\
\hline Histidine-rich glycoprotein (HRG) & $\mathrm{P} 04196$ & $1 \mathrm{~d}$ & $\sim 35$ & 1.7 up & $<0.02$ & NS & NS & 2.9 up & $<0.002$ & 2 & $161 / 4$ & Putative cleavage product \\
\hline Unidentified Series & $\mathrm{n} / \mathrm{a}$ & $1 \mathrm{e}$ & $\sim 40$ & 1.5 down & $<0.05$ & NS & NS & NS & NS & - & $\mathrm{n} / \mathrm{a}$ & Low abundant species \\
\hline Haptoglobin (Hpt) heavy chain & $\mathrm{P} 00738$ & $2 a$ & 40 & 2.0 up & $<0.01$ & NS & NS & 2.2 up & $<0.02$ & 2 & $238 / 13$ & Summation of variants \\
\hline Haptoglobin $(\mathrm{Hpt})$ mid chain & P00738 & $2 b$ & 16 & NS & NS & NS & NS & NS & NS & 2 & $*$ & NS changing subunit of $\mathrm{Hpt}$ \\
\hline Haptoglobin (Hpt) light chain & P00738 & $2 \mathrm{c}$ & 9 & 2.4 up & $<0.02$ & NS & NS & NS & NS & 2 & $*$ & Summation of variants \\
\hline Vitamin D binding protein (VDBP) & $\mathrm{P} 02774$ & $3 \mathrm{~b}$ & $\sim 50$ & NS & NS & \multicolumn{4}{|c|}{ See figure 5} & & & Cleavage products \\
\hline Vitamin D binding protein (VDBP) & $\mathrm{P} 02774$ & $3 \mathrm{c}$ & $\sim 40$ & NS & NS & \multicolumn{4}{|c|}{ See figure 5} & & & Multiple cleavage products \\
\hline Vitamin D binding protein (VDBP) & P02774 & $3 \mathrm{~d}$ & $\sim 10$ & NS & NS & \multicolumn{4}{|c|}{ See figure 5} & & & Multiple cleavage products \\
\hline Inter $\alpha$ trypsin inhibitor heavy chain H4 (ITIH4) & Q14624 & $3 \mathrm{e}$ & $\sim 12$ & 1.3 up & $<0.05$ & NS & NS & NS & NS & 3 & $428 / 5$ & C-term clevage product \\
\hline Complement factor 1(CFI) & $\mathrm{P} 05156$ & $3 \mathrm{f}$ & $\sim 53$ & NS & NS & 2.5 up & $<0.01$ & 2.6 down & $<0.02$ & 2 & $64 / 2$ & Putative cleavage product \\
\hline Complement factor 1(CFI) & $\mathrm{P} 05156$ & $3 \mathrm{~g}$ & $\sim 53$ & NS & NS & 2.0 up & $<0.001$ & 2.4 down & $<0.03$ & 2 & $78 / 2$ & Putative cleavage product \\
\hline Complement factor 1(CFI) & P05156 & $3 \mathrm{~h}$ & $\sim 53$ & NS & NS & 3.6 up & 0.056 & 3.1 down & $<0.03$ & 2 & $127 / 4$ & Putative cleavage product \\
\hline Complement factor 1(CFI) & P05156 & $3 \mathrm{i}$ & $\sim 53$ & NS & NS & 4.0 up & $<0.1$ & 3.1 down & 0.058 & 2 & $69 / 1$ & NS but trending \\
\hline Inter $\alpha$ trypsin inhibitor heavy chain H4 (ITIH4) & Q14624 & $4 \mathrm{a}$ & $\sim 40$ & 1.3 up & $<0.05$ & 1.5 up & $<0.02$ & NS & NS & 3 & $890 / 14$ & $\mathrm{~N}$-term cleavage product \\
\hline C-reactive binding protein (CRP) & $\mathrm{P} 02741$ & $4 \mathrm{~b}$ & 25 & 3.2 up & 0.19 & NS & NS & NS & NS & 1 & $96 / 2$ & NS change \\
\hline C-reactive binding protein (CRP) & $\mathrm{P} 02741$ & $4 \mathrm{c}$ & 25 & 2.9 up & 0.09 & NS & NS & NS & NS & 1 & NS & NS change \\
\hline C-reactive binding protein (CRP) & P02741 & $4 \mathrm{~d}$ & 25 & 2.4 up & 0.18 & NS & NS & NS & NS & 1 & NS & NS change \\
\hline C-reactive binding protein (CRP) & P02741 & $4 \mathrm{e}$ & 25 & 2.2 up & 0.06 & NS & NS & NS & NS & 1 & NS & NS but trending \\
\hline$\alpha 1$-antitrypsin $(\alpha 1 \mathrm{AT})$ & P01009 & $5 \mathrm{a}$ & $\sim 47$ & 3.3 & $<0.02$ & NS & NS & NS & NS & 2 & $86 / 3$ & \\
\hline Apolipoprotein E (ApoE) & P02649 & $5 b$ & 34 & 1.5 up & $<0.02$ & NS & NS & NS & NS & 2 & $149 / 7$ & Epsilon 4 proxy \\
\hline
\end{tabular}

$\mathrm{NS}=$ Not submitted. Based on continuity of spot train in 8 . 
medRxiv preprint doi: https://doi.org/10.1101/2020.04.15.20066647; this version posted April 18, 2020. The copyright holder for this preprint (which was not certified by peer review) is the author/funder, who has granted medRxiv a license to display the preprint in perpetuity. All rights reserved. No reuse allowed without permission.

1 Table 3. Demographic data for plasma samples used for targeted mass spectrometry biomarker

2 validation.

\begin{tabular}{cccc}
\hline & Controls & Alzheimer Disease & p-value \\
\hline Age in years & $72.9(6)$ & $76.9(7.4)$ & $0.003^{*}$ \\
$\%$ APOE \&4 & 13 & 37 & $0.01^{\#}$ \\
$\%$ APOE \& 2 & 20.5 & 6.8 & $0.06^{\#}$ \\
$\%$ Female & 50 & 50 & \\
Amyloid PET SUVR & $1.17(0.05)$ & $2.35(0.49)^{\wedge}$ & $2 \mathrm{e}-10$ \\
$\mathrm{n}$ & 44 & 44 & \\
\hline
\end{tabular}

3 *p-value calculated using non-paired Student's t-test

$4 \quad \#$ p-value for APOE allele frequency calculated using N-1 $\chi^{2}$

$5 \wedge$ PET scans are only available for 22 of the 44 cases.

6 
medRxiv preprint doi: https://doi.org/10.1101/2020.04.15.20066647; this version posted April 18, 2020. The copyright holder for this preprint (which was not certified by peer review) is the author/funder, who has granted medRxiv a license to display the preprint in perpetuity. All rights reserved. No reuse allowed without permission.

1 Table 4. Receiver operating characteristic (ROC) analysis of proteins measured by targeted LC-

2 MS assay showing ability to distinguish controls $(n=44)$ from Alzheimer's case $(n=44)$.

\begin{tabular}{lcccc}
\hline Protein ID & AUC & Sensitivity \% & Specificity \% & p-value \\
\hline Complement C3 & 0.65 & 69.8 & 59.1 & 0.014 \\
Beta-2-Microglobulin & 0.64 & 47.8 & 80 & 0.022 \\
Peroxiredoxin-2 & 0.60 & - & - & 0.098
\end{tabular}


medRxiv preprint doi: https://doi.org/10.1101/2020.04.15.20066647; this version posted April 18, 2020. The copyright holder for this preprint (which was not certified by peer review) is the author/funder, who has granted medRxiv a license to display the preprint in perpetuity.

\section{Abbreviations}

$2 \quad \alpha 1$-Anti-trypsin, $\alpha 1$ AT; $\alpha 1$ Anti-chymotrypsin, $\alpha 1$ ACT; Acute-phase reactant, APR; Alzheimer's

3 disease, AD; Amyloid precursor protein, APP; Amyloid $\beta$ peptide, A $\beta$; Apolipoprotein E protein,

4 ApoE; Blood-brain barrier, BBB; Body mass index, BMI; C-reactive protein, CRP; Central

5 Nervous System, CNS; Cerebrospinal fluid, CSF; Haptoglobin, Hpt; Healthy control, HC;

6 Histidine-rich glycoprotein, HRG; Inter- $\alpha$ trypsin inhibitor, ITIH; Isoelectric focusing IEF,

7 Isoelectric point pI; Kunitz-type protease inhibitor, KPI; Reverse phase high pressure liquid

8 chromatography, RP-HPLC; Vitamin D binding protein, VDBP; Zinc $\alpha$ 2-glycoprotein, ZAG

9 Competing interests

10 EAD and PAG are founders and shareholders in Zdye LLC, which licenses patents issued to

11 Montana State University and reagents used in the present study. BRR, SBL and EAD are

12 inventors on PCT application AU2014/000849. BRR receives research support from Agilent

13 Technologies and from eMSion Inc. (OR, USA). All other authors declare that no competing

14 interests exist.

\section{Acknowledgments}

16 We would like to acknowledge the Australian Imaging and Biomarker, Lifestyle (AIBL)

17 research team (a complete list of researchers can be found at www.aibl.csiro.au) and the

18 volunteers and their families. We would also like to acknowledge funding from the Dementia

19 Collaborative Research Centres (DCRC), The Victorian Government's Operational

20 Infrastructure Support Program and the Wicking Trust. National Institutes of Health- Small

21 Business Technology Transfer (NIH STTR grant 5R42RR021790, EAD PI), Center for

22 Biological Research Excellence (NIH CoBRE grants 1P20RR024237 and 2P20GM 104935,

23 EAD PI), Montana Board of Research and Commercialization Technology Grants: (MBRCT:

24 05-14, 06-46, and 08-17, EAD PI) and the Murdock Charitable Trust (EAD, PI). The

25 Cooperative Research Centre for Mental Health, Alzheimer's Drug Discovery Foundation grant

26 (BRR, PI), Knott Family Equipment Grant (BRR, PI), the Pierce Armstrong Trust (BRR, PI),

27 NHMRC Dementia Leadership Fellowship (BR, APP1138673), and NHMRC project grant (BR,

28 APP1164692). The Florey Neuroproteomics Facility. We would like to thank the Melbourne

29 Mass Spectrometry and Proteomics Facility of The Bio21 Molecular Science and Biotechnology

30 Institute at The University of Melbourne for the support of mass spectrometry analysis. 
medRxiv preprint doi: https://doi.org/10.1101/2020.04.15.20066647; this version posted April 18, 2020. The copyright holder for this preprint (which was not certified by peer review) is the author/funder, who has granted medRxiv a license to display the preprint in perpetuity.

\section{Data availability statement}

The proteomics data used to support the findings of this study are available from the corresponding author upon request.

\section{References}

1. Alzheimer's, A. (2014) 2014 Alzheimer's disease facts and figures. Alzheimers Dement 10, e47-92

2. Barnett, J. H., Lewis, L., Blackwell, A. D., and Taylor, M. (2014) Early intervention in Alzheimer's disease: a health economic study of the effects of diagnostic timing. BMC neurology 14, 101

3. Breteler, M. M. (2001) Early life circumstances and late life Alzheimer's disease. Epidemiology 12, 378-379

4. Jellinger, K. A., Janetzky, B., Attems, J., and Kienzl, E. (2008) Biomarkers for early diagnosis of Alzheimer disease: 'ALZheimer ASsociated gene'--a new blood biomarker? Journal of cellular and molecular medicine 12, 1094-1117

5. Villemagne, V. L., Burnham, S., Bourgeat, P., Brown, B., Ellis, K. A., Salvado, O., Szoeke, C., Macaulay, S. L., Martins, R., Maruff, P., Ames, D., Rowe, C. C., Masters, C. L., Australian Imaging, B., and Lifestyle Research, G. (2013) Amyloid beta deposition, neurodegeneration, and cognitive decline in sporadic Alzheimer's disease: a prospective cohort study. The Lancet. Neurology 12, 357-367

6. Blennow, K., Dubois, B., Fagan, A. M., Lewczuk, P., de Leon, M. J., and Hampel, H. (2015) Clinical utility of cerebrospinal fluid biomarkers in the diagnosis of early Alzheimer's disease. Alzheimers Dement 11, 58-69

7. Holtzman, D. M. (2011) CSF biomarkers for Alzheimer's disease: current utility and potential future use. Neurobiol Aging 32 Suppl 1, S4-9

8. Starr, J. M., Farrall, A. J., Armitage, P., McGurn, B., and Wardlaw, J. (2009) Blood-brain barrier permeability in Alzheimer's disease: a case-control MRI study. Psychiatry research 171, 232-241

9. Zipser, B. D., Johanson, C. E., Gonzalez, L., Berzin, T. M., Tavares, R., Hulette, C. M., Vitek, M. P., Hovanesian, V., and Stopa, E. G. (2007) Microvascular injury and bloodbrain barrier leakage in Alzheimer's disease. Neurobiol Aging 28, 977-986

10. Banks, W. A. (2012) Brain meets body: the blood-brain barrier as an endocrine interface. Endocrinology 153, 4111-4119

11. Hartai, Z., Juhász, A., Rimanóczy, Á., Janáky, T., Donkó, T., Dux, L., Penke, B., Tóth, G. K., Janka, Z., and Kálmán, J. (2007) Decreased serum and red blood cell kynurenic acid levels in Alzheimer's disease. Neurochemistry international 50, 308-313

12. Mohanty, J. G., Shukla, H. D., Williamson, J. D., Launer, L. J., Saxena, S., and Rifkind, J. M. (2010) Alterations in the red blood cell membrane proteome in alzheimer's subjects reflect disease-related changes and provide insight into altered cell morphology. Proteome science $\mathbf{8}, 11$

13. Faux, N. G., Rembach, A., Wiley, J., Ellis, K. A., Ames, D., Fowler, C. J., Martins, R. N., Pertile, K. K., Rumble, R. L., Trounson, B., Masters, C. L., Group, A. R., and Bush, A. I. (2014) An anemia of Alzheimer's disease. Mol Psychiatry 19, 1227-1234

14. Ryan, T. M., Roberts, B. R., McColl, G., Hare, D. J., Doble, P. A., Li, Q. X., Lind, M., Roberts, A. M., Mertens, H. D., Kirby, N., Pham, C. L., Hinds, M. G., Adlard, P. A., 
Barnham, K. J., Curtain, C. C., and Masters, C. L. (2015) Stabilization of nontoxic Abeta-oligomers: insights into the mechanism of action of hydroxyquinolines in Alzheimer's disease. J Neurosci 35, 2871-2884

15. Fu, T.-K., Matsuyama, S. S., Kessler, J. O., and Jarvik, L. F. (1986) Philothermal response, microtubules and dementia. Neurobiology of aging 7, 41-43

16. Jarvik, L. F., Matsuyama, S. S., Kessler, J. O., Fu, T.-k., Tsau, S., and Clark, E. O. (1982) Philothermal response of polymorphonuclear leukocytes in dementia of the Alzheimer type. Neurobiology of aging 3, 93-99

17. Scott, R. B., Collins, J. M., and Hunt, P. A. (1994) Alzheimer's disease and Down syndrome: leukocyte membrane fluidity alterations. Mechanisms of ageing and development 75, 1-10

18. Burnham, S. C., Faux, N. G., Wilson, W., Laws, S. M., Ames, D., Bedo, J., Bush, A. I., Doecke, J. D., Ellis, K. A., Head, R., Jones, G., Kiiveri, H., Martins, R. N., Rembach, A., Rowe, C. C., Salvado, O., Macaulay, S. L., Masters, C. L., Villemagne, V. L., Alzheimer's Disease Neuroimaging, I., Australian Imaging, B., and Lifestyle Study Research, G. (2014) A blood-based predictor for neocortical Abeta burden in Alzheimer's disease: results from the AIBL study. Mol Psychiatry 19, 519-526

19. Doecke, J. D., Laws, S. M., Faux, N. G., Wilson, W., Burnham, S. C., Lam, C. P., Mondal, A., Bedo, J., Bush, A. I., Brown, B., De Ruyck, K., Ellis, K. A., Fowler, C., Gupta, V. B., Head, R., Macaulay, S. L., Pertile, K., Rowe, C. C., Rembach, A., Rodrigues, M., Rumble, R., Szoeke, C., Taddei, K., Taddei, T., Trounson, B., Ames, D., Masters, C. L., Martins, R. N., Alzheimer's Disease Neuroimaging, I., Australian Imaging, B., and Lifestyle Research, G. (2012) Blood-based protein biomarkers for diagnosis of Alzheimer disease. Arch Neurol 69, 1318-1325

20. Guo, L. H., Alexopoulos, P., Wagenpfeil, S., Kurz, A., Perneczky, R., and Alzheimer's Disease Neuroimaging, I. (2013) Plasma proteomics for the identification of Alzheimer disease. Alzheimer Dis Assoc Disord 27, 337-342

21. Hye, A., Lynham, S., Thambisetty, M., Causevic, M., Campbell, J., Byers, H. L., Hooper, C., Rijsdijk, F., Tabrizi, S. J., Banner, S., Shaw, C. E., Foy, C., Poppe, M., Archer, N., Hamilton, G., Powell, J., Brown, R. G., Sham, P., Ward, M., and Lovestone, S. (2006) Proteome-based plasma biomarkers for Alzheimer's disease,

22. Llano, D. A., Devanarayan, V., Simon, A. J., and Alzheimer's Disease Neuroimaging, I. (2013) Evaluation of plasma proteomic data for Alzheimer disease state classification and for the prediction of progression from mild cognitive impairment to Alzheimer disease. Alzheimer Dis Assoc Disord 27, 233-243

23. Song, F., Poljak, A., Kochan, N. A., Raftery, M., Brodaty, H., Smythe, G. A., and Sachdev, P. S. (2014) Plasma protein profiling of Mild Cognitive Impairment and Alzheimer's disease using iTRAQ quantitative proteomics. Proteome science 12, 5

24. Muenchhoff, J., Poljak, A., Song, F., Raftery, M., Brodaty, H., Duncan, M., McEvoy, M., Attia, J., Schofield, P. W., and Sachdev, P. S. (2015) Plasma protein profiling of mild cognitive impairment and Alzheimer's disease across two independent cohorts. $J$ Alzheimers Dis 43, 1355-1373

25. Hye, A., Lynham, S., Thambisetty, M., Causevic, M., Campbell, J., Byers, H. L., Hooper, C., Rijsdijk, F., Tabrizi, S. J., Banner, S., Shaw, C. E., Foy, C., Poppe, M., Archer, N., Hamilton, G., Powell, J., Brown, R. G., Sham, P., Ward, M., and Lovestone, S. (2006) Proteome-based plasma biomarkers for Alzheimer's disease. Brain 129, 3042-3050 
26. Lonneborg, A. (2008) Biomarkers for Alzheimer disease in cerebrospinal fluid, urine, and blood. Molecular diagnosis \& therapy 12, 307-320

27. Snyder, H. M., Corriveau, R. A., Craft, S., Faber, J. E., Greenberg, S. M., Knopman, D., Lamb, B. T., Montine, T. J., Nedergaard, M., Schaffer, C. B., Schneider, J. A., Wellington, C., Wilcock, D. M., Zipfel, G. J., Zlokovic, B., Bain, L. J., Bosetti, F., Galis, Z. S., Koroshetz, W., and Carrillo, M. C. (2014) Vascular contributions to cognitive impairment and dementia including Alzheimer's disease. Alzheimers Dement

28. Teunissen, C. E., de Vente, J., Steinbusch, H. W., and De Bruijn, C. (2002) Biochemical markers related to Alzheimer's dementia in serum and cerebrospinal fluid. Neurobiol Aging 23, 485-508

29. Thambisetty, M., Simmons, A., Hye, A., Campbell, J., Westman, E., Zhang, Y., Wahlund, L. O., Kinsey, A., Causevic, M., Killick, R., Kloszewska, I., Mecocci, P., Soininen, H., Tsolaki, M., Vellas, B., Spenger, C., Lovestone, S., and AddNeuroMed, C. (2011) Plasma biomarkers of brain atrophy in Alzheimer's disease. PLoS One 6, e28527

30. Chen, Z., Mengel, D., Keshavan, A., Rissman, R. A., Billinton, A., Perkinton, M., Percival-Alwyn, J., Schultz, A., Properzi, M., Johnson, K., Selkoe, D. J., Sperling, R. A., Patel, P., Zetterberg, H., Galasko, D., Schott, J. M., and Walsh, D. M. (2019) Learnings about the complexity of extracellular tau aid development of a blood-based screen for Alzheimer's disease. Alzheimer's \& dementia : the journal of the Alzheimer's Association 15, 487-496

31. Lue, L. F., Sabbagh, M. N., Chiu, M. J., Jing, N., Snyder, N. L., Schmitz, C., Guerra, A., Belden, C. M., Chen, T. F., Yang, C. C., Yang, S. Y., Walker, D. G., Chen, K., and Reiman, E. M. (2017) Plasma Levels of Abeta42 and Tau Identified Probable Alzheimer's Dementia: Findings in Two Cohorts. Frontiers in aging neuroscience 9, 226

32. Nakamura, A., Kaneko, N., Villemagne, V. L., Kato, T., Doecke, J., Dore, V., Fowler, C., Li, Q. X., Martins, R., Rowe, C., Tomita, T., Matsuzaki, K., Ishii, K., Ishii, K., Arahata, Y., Iwamoto, S., Ito, K., Tanaka, K., Masters, C. L., and Yanagisawa, K. (2018) High performance plasma amyloid-beta biomarkers for Alzheimer's disease. Nature 554, 249254

33. Risacher, S. L., Fandos, N., Romero, J., Sherriff, I., Pesini, P., Saykin, A. J., and Apostolova, L. G. (2019) Plasma amyloid beta levels are associated with cerebral amyloid and tau deposition. Alzheimers Dement (Amst) 11, 510-519

34. Schindler, S. E., Bollinger, J. G., Ovod, V., Mawuenyega, K. G., Li, Y., Gordon, B. A., Holtzman, D. M., Morris, J. C., Benzinger, T. L. S., Xiong, C., Fagan, A. M., and Bateman, R. J. (2019) High-precision plasma beta-amyloid 42/40 predicts current and future brain amyloidosis. Neurology 93, e1647-e1659

35. Abdi, F., Quinn, J. F., Jankovic, J., McIntosh, M., Leverenz, J. B., Peskind, E., Nixon, R., Nutt, J., Chung, K., Zabetian, C., Samii, A., Lin, M., Hattan, S., Pan, C., Wang, Y., Jin, J., Zhu, D., Li, G. J., Liu, Y., Waichunas, D., Montine, T. J., and Zhang, J. (2006) Detection of biomarkers with a multiplex quantitative proteomic platform in cerebrospinal fluid of patients with neurodegenerative disorders. J Alzheimers Dis 9, 293348

36. Anderson, N. L., and Anderson, N. G. (2002) The human plasma proteome: history, character, and diagnostic prospects. Mol Cell Proteomics 1, 845-867 
medRxiv preprint doi: https://doi.org/10.1101/2020.04.15.20066647; this version posted April 18, 2020. The copyright holder for this preprint (which was not certified by peer review) is the author/funder, who has granted medRxiv a license to display the preprint in perpetuity.

37. Jacobs, J. M., Adkins, J. N., Qian, W. J., Liu, T., Shen, Y., Camp, D. G., 2nd, and Smith, R. D. (2005) Utilizing human blood plasma for proteomic biomarker discovery. $J$ Proteome Res 4, 1073-1085

38. Zolotarjova, N., Mrozinski, P., Chen, H., and Martosella, J. (2008) Combination of affinity depletion of abundant proteins and reversed-phase fractionation in proteomic analysis of human plasma/serum. J Chromatogr A 1189, 332-338

39. Diz, A. P., Truebano, M., and Skibinski, D. O. (2009) The consequences of sample pooling in proteomics: an empirical study. Electrophoresis 30, 2967-2975

40. Oberg, A. L., and Vitek, O. (2009) Statistical design of quantitative mass spectrometrybased proteomic experiments. J Proteome Res 8, 2144-2156

41. Dratz, E. A., and Grieco, P. A. (2010) Zwitterionic dyes for labeling in proteomic and other biological analyses. Google Patents

42. Epstein, M. G., Reeves, B. D., Maaty, W. S., Fouchard, D., Dratz, E. A., Bothner, B., and Grieco, P. A. (2013) Enhanced sensitivity employing zwitterionic and pI balancing dyes (Z-CyDyes) optimized for 2D-gel electrophoresis based on side chain modifications of CyDye fluorophores. New tools for use in proteomics and diagnostics. Bioconjugate chemistry 24, 1552-1561

43. Ellis, K. A., Bush, A. I., Darby, D., De Fazio, D., Foster, J., Hudson, P., Lautenschlager, N. T., Lenzo, N., Martins, R. N., Maruff, P., Masters, C., Milner, A., Pike, K., Rowe, C., Savage, G., Szoeke, C., Taddei, K., Villemagne, V., Woodward, M., and Ames, D. (2009) The Australian Imaging, Biomarkers and Lifestyle (AIBL) study of aging: methodology and baseline characteristics of 1112 individuals recruited for a longitudinal study of Alzheimer's disease. Int Psychogeriatr 21, 672-687

44. McKhann, G. M., Knopman, D. S., Chertkow, H., Hyman, B. T., Jack, C. R., Jr., Kawas, C. H., Klunk, W. E., Koroshetz, W. J., Manly, J. J., Mayeux, R., Mohs, R. C., Morris, J. C., Rossor, M. N., Scheltens, P., Carrillo, M. C., Thies, B., Weintraub, S., and Phelps, C. H. (2011) The diagnosis of dementia due to Alzheimer's disease: recommendations from the National Institute on Aging-Alzheimer's Association workgroups on diagnostic guidelines for Alzheimer's disease. Alzheimer's \& dementia : the journal of the Alzheimer's Association 7, 263-269

45. Storey, J. D., and Tibshirani, R. (2003) Statistical significance for genomewide studies. Proc Natl Acad Sci U S A 100, 9440-9445

46. Shevchenko, A., Tomas, H., Havlis, J., Olsen, J. V., and Mann, M. (2006) In-gel digestion for mass spectrometric characterization of proteins and proteomes. Nat Protoc 1, 2856-2860

47. Heffernan, A. L., Chidgey, C., Peng, P., Masters, C. L., and Roberts, B. R. (2016) The Neurobiology and Age-Related Prevalence of the epsilon4 Allele of Apolipoprotein E in Alzheimer's Disease Cohorts. J Mol Neurosci 60, 316-324

48. Pike, K. E., Savage, G., Villemagne, V. L., Ng, S., Moss, S. A., Maruff, P., Mathis, C. A., Klunk, W. E., Masters, C. L., and Rowe, C. C. (2007) Beta-amyloid imaging and memory in non-demented individuals: evidence for preclinical Alzheimer's disease. Brain 130, 2837-2844

49. Langlois, M. R., and Delanghe, J. R. (1996) Biological and clinical significance of haptoglobin polymorphism in humans. Clin Chem 42, 1589-1600 
medRxiv preprint doi: https://doi.org/10.1101/2020.04.15.20066647; this version posted April 18, 2020. The copyright holder for this preprint (which was not certified by peer review) is the author/funder, who has granted medRxiv a license to display the preprint in perpetuity.

50. Wernette-Hammond, M. E., Lauer, S. J., Corsini, A., Walker, D., Taylor, J. M., and Rall, S. C., Jr. (1989) Glycosylation of human apolipoprotein E. The carbohydrate attachment site is threonine 194. J Biol Chem 264, 9094-9101

51. Sarioglu, H., Lottspeich, F., Walk, T., Jung, G., and Eckerskorn, C. (2000) Deamidation as a widespread phenomenon in two-dimensional polyacrylamide gel electrophoresis of human blood plasma proteins. Electrophoresis 21, 2209-2218

52. Davidsson, P., Westman-Brinkmalm, A., Nilsson, C. L., Lindbjer, M., Paulson, L., Andreasen, N., Sjogren, M., and Blennow, K. (2002) Proteome analysis of cerebrospinal fluid proteins in Alzheimer patients. Neuroreport 13, 611-615

53. Dominici, R., Finazzi, D., Polito, L., Oldoni, E., Bugari, G., Montanelli, A., Scarpini, E., Galimberti, D., and Guaita, A. (2018) Comparison of beta2-microglobulin serum level between Alzheimer's patients, cognitive healthy and mild cognitive impaired individuals. Biomarkers : biochemical indicators of exposure, response, and susceptibility to chemicals 23, 603-608

54. Yoshida, Y., Yoshikawa, A., Kinumi, T., Ogawa, Y., Saito, Y., Ohara, K., Yamamoto, H., Imai, Y., and Niki, E. (2009) Hydroxyoctadecadienoic acid and oxidatively modified peroxiredoxins in the blood of Alzheimer's disease patients and their potential as biomarkers. Neurobiol Aging 30, 174-185

55. Dai, J., Johnson, E. C. B., Dammer, E. B., Duong, D. M., Gearing, M., Lah, J. J., Levey, A. I., Wingo, T. S., and Seyfried, N. T. (2018) Effects of APOE Genotype on Brain Proteomic Network and Cell Type Changes in Alzheimer's Disease. Front Mol Neurosci 11, 454

56. Choi, J., Malakowsky, C. A., Talent, J. M., Conrad, C. C., and Gracy, R. W. (2002) Identification of oxidized plasma proteins in Alzheimer's disease. Biochem Biophys Res Commun 293, 1566-1570

57. Liao, P. C., Yu, L., Kuo, C. C., Lin, C., and Kuo, Y. M. (2007) Proteomics analysis of plasma for potential biomarkers in the diagnosis of Alzheimer's disease. Proteomics Clin Appl 1, 506-512

58. Yu, H. L., Chertkow, H. M., Bergman, H., and Schipper, H. M. (2003) Aberrant profiles of native and oxidized glycoproteins in Alzheimer plasma. Proteomics 3, 2240-2248

59. Finehout, E. J., Franck, Z., Choe, L. H., Relkin, N., and Lee, K. H. (2007) Cerebrospinal fluid proteomic biomarkers for Alzheimer's disease. Ann Neurol 61, 120-129

60. Puchades, M., Hansson, S. F., Nilsson, C. L., Andreasen, N., Blennow, K., and Davidsson, P. (2003) Proteomic studies of potential cerebrospinal fluid protein markers for Alzheimer's disease. Brain Res Mol Brain Res 118, 140-146

61. Gollin, P. A., Kalaria, R. N., Eikelenboom, P., Rozemuller, A., and Perry, G. (1992) Alpha 1-antitrypsin and alpha 1-antichymotrypsin are in the lesions of Alzheimer's disease. Neuroreport 3, 201-203

62. Kowalska, A., Danker-Hopfe, H., Wender, M., Florczak, J., and Walter, H. (1996) Association between the PI* M3 allele of $\alpha 1$-antitrypsin and Alzheimer's disease? A preliminary report. Human genetics $\mathbf{9 8 , 7 4 4 - 7 4 6}$

63. Licastro, F., Pedrini, S., Ferri, C., Casadei, V., Govoni, M., Pession, A., Sciacca, F. L., Veglia, F., Annoni, G., Bonafe, M., Olivieri, F., Franceschi, C., and Grimaldi, L. M. (2000) Gene polymorphism affecting alpha1-antichymotrypsin and interleukin-1 plasma levels increases Alzheimer's disease risk. Ann Neurol 48, 388-391 
medRxiv preprint doi: https://doi.org/10.1101/2020.04.15.20066647; this version posted April 18, 2020. The copyright holder for this preprint (which was not certified by peer review) is the author/funder, who has granted medRxiv a license to display the preprint in perpetuity.

64. Licastro, F., Pedrini, S., Govoni, M., Pession, A., Ferri, C., Annoni, G., Casadei, V., Veglia, F., Bertolini, S., and Grimaldi, L. M. (1999) Apolipoprotein E and alpha-1antichymotrypsin allele polymorphism in sporadic and familial Alzheimer's disease. Neurosci Lett 270, 129-132

65. Engelhart, M. J., Geerlings, M. I., Meijer, J., Kiliaan, A., Ruitenberg, A., van Swieten, J. C., Stijnen, T., Hofman, A., Witteman, J. C., and Breteler, M. M. (2004) Inflammatory proteins in plasma and the risk of dementia: the rotterdam study. Arch Neurol 61, 668672

66. Licastro, F., Pedrini, S., Caputo, L., Annoni, G., Davis, L. J., Ferri, C., Casadei, V., and Grimaldi, L. M. (2000) Increased plasma levels of interleukin-1, interleukin-6 and alpha1-antichymotrypsin in patients with Alzheimer's disease: peripheral inflammation or signals from the brain? Journal of neuroimmunology 103, 97-102

67. Nielsen, H., Minthon, L., Londos, E., Blennow, K., Miranda, E., Perez, J., Crowther, D., Lomas, D., and Janciauskiene, S. (2007) Plasma and CSF serpins in Alzheimer disease and dementia with Lewy bodies. Neurology 69, 1569-1579

68. Abraham, C. R., Selkoe, D. J., and Potter, H. (1988) Immunochemical identification of the serine protease inhibitor alpha 1-antichymotrypsin in the brain amyloid deposits of Alzheimer's disease. Cell 52, 487-501

69. Strittmatter, W. J., Saunders, A. M., Schmechel, D., Pericak-Vance, M., Enghild, J., Salvesen, G. S., and Roses, A. D. (1993) Apolipoprotein E: high-avidity binding to betaamyloid and increased frequency of type 4 allele in late-onset familial Alzheimer disease. Proc Natl Acad Sci U S A 90, 1977-1981

70. Licastro, F., Masliah, E., Pedrini, S., and Thal, L. J. (1999) Blood levels of alpha-1antichymotrypsin and risk factors for Alzheimer's disease: effects of gender and apolipoprotein E genotype. Dementia and geriatric cognitive disorders 11, 25-28

71. Porcellini, E., Davis, E. J., Chiappelli, M., Ianni, E., Di Stefano, G., Forti, P., Ravaglia, G., and Licastro, F. (2008) Elevated plasma levels of alpha-1-anti-chymotrypsin in agerelated cognitive decline and Alzheimer's disease: a potential therapeutic target. Curr Pharm Des 14, 2659-2664

72. Scacchi, R., Ruggeri, M., Gambina, G., Martini, M. C., Ferrari, G., and Corbo, R. M. (2001) Plasma alpha1-antichymotrypsin in Alzheimer's disease; relationships with APOE genotypes. Neurobiol Aging 22, 413-416

73. Nilsson, L. N., Bales, K. R., DiCarlo, G., Gordon, M. N., Morgan, D., Paul, S. M., and Potter, H. (2001) Alpha-1-antichymotrypsin promotes beta-sheet amyloid plaque deposition in a transgenic mouse model of Alzheimer's disease. J Neurosci 21, 14441451

74. Padmanabhan, J., Levy, M., Dickson, D. W., and Potter, H. (2006) Alpha1antichymotrypsin, an inflammatory protein overexpressed in Alzheimer's disease brain, induces tau phosphorylation in neurons. Brain 129, 3020-3034

75. Giunta, S., Galeazzi, R., Marcellini, M., Corder, E., and Galeazzi, L. (2007) The inflammation-sensitive protein alpha 1-anti-chymotrypsin neutralizes fibrillar aggregation and cytotoxicity of the beta-amyloid peptide more effectively than alpha 1-antitrypsin. Clinical biochemistry 40, 887-892

76. Holmes, C. (2013) Review: systemic inflammation and Alzheimer's disease. Neuropathol Appl Neurobiol 39, 51-68 
medRxiv preprint doi: https://doi.org/10.1101/2020.04.15.20066647; this version posted April 18, 2020. The copyright holder for this preprint (which was not certified by peer review) is the author/funder, who has granted medRxiv a license to display the preprint in perpetuity.

All rights reserved. No reuse allowed without permission.

77. Zhang, R., Barker, L., Pinchev, D., Marshall, J., Rasamoelisolo, M., Smith, C., Kupchak, P., Kireeva, I., Ingratta, L., and Jackowski, G. (2004) Mining biomarkers in human sera using proteomic tools. Proteomics 4, 244-256

78. Mortensen, R. F. (2001) C-reactive protein, inflammation, and innate immunity. Immunologic research 24, 163-176

79. Bode, J. G., Albrecht, U., Haussinger, D., Heinrich, P. C., and Schaper, F. (2012) Hepatic acute phase proteins--regulation by IL-6- and IL-1-type cytokines involving STAT3 and its crosstalk with NF-kappaB-dependent signaling. European journal of cell biology $\mathbf{9 1}$, 496-505

80. Wood, J. A., Wood, P. L., Ryan, R., Graff-Radford, N. R., Pilapil, C., Robitaille, Y., and Quirion, R. (1993) Cytokine indices in Alzheimer's temporal cortex: no changes in mature IL-1 beta or IL-1RA but increases in the associated acute phase proteins IL-6, alpha 2-macroglobulin and C-reactive protein. Brain Res 629, 245-252

81. Hirai, K., Hussey, H. J., Barber, M. D., Price, S. A., and Tisdale, M. J. (1998) Biological evaluation of a lipid-mobilizing factor isolated from the urine of cancer patients. Cancer research 58, 2359-2365

82. Selva, D. M., Lecube, A., Hernandez, C., Baena, J. A., Fort, J. M., and Simo, R. (2009) Lower zinc-alpha2-glycoprotein production by adipose tissue and liver in obese patients unrelated to insulin resistance. The Journal of clinical endocrinology and metabolism 94, 4499-4507

83. Roher, A. E., Maarouf, C. L., Sue, L. I., Hu, Y., Wilson, J., and Beach, T. G. (2009) Proteomics-derived cerebrospinal fluid markers of autopsy-confirmed Alzheimer's disease. Biomarkers : biochemical indicators of exposure, response, and susceptibility to chemicals 14, 493-501

84. Shah, R. C., Buchman, A. S., Wilson, R. S., Leurgans, S. E., and Bennett, D. A. (2011) Hemoglobin level in older persons and incident Alzheimer disease: prospective cohort analysis. Neurology 77, 219-226

85. Barnes, L. L., Wilson, R. S., Bienias, J. L., Schneider, J. A., Evans, D. A., and Bennett, D. A. (2005) Sex differences in the clinical manifestations of Alzheimer disease pathology. Archives of General Psychiatry 62, 685-691

86. Ruitenberg, A., Ott, A., van Swieten, J. C., Hofman, A., and Breteler, M. M. (2001) Incidence of dementia: does gender make a difference? Neurobiology of aging 22, 575580

87. Kawakami, M., Blum, C. B., Ramakrishnan, R., Dell, R. B., and Goodman, D. S. (1981) Turnover of the plasma binding protein for vitamin $\mathrm{D}$ and its metabolites in normal human subjects. The Journal of clinical endocrinology and metabolism 53, 1110-1116

88. White, P., and Cooke, N. (2000) The multifunctional properties and characteristics of vitamin D-binding protein. Trends in endocrinology and metabolism: TEM 11, 320-327

89. Disanto, G., Ramagopalan, S. V., Para, A. E., and Handunnetthi, L. (2011) The emerging role of vitamin D binding protein in multiple sclerosis. J Neurol 258, 353-358

90. Bouillon, R., Van Assche, F. A., Van Baelen, H., Heyns, W., and De Moor, P. (1981) Influence of the vitamin D-binding protein on the serum concentration of 1,25dihydroxyvitamin D3. Significance of the free 1,25-dihydroxyvitamin D3 concentration. The Journal of clinical investigation 67, 589-596

91. Blanton, D., Han, Z., Bierschenk, L., Linga-Reddy, M. V., Wang, H., Clare-Salzler, M., Haller, M., Schatz, D., Myhr, C., She, J. X., Wasserfall, C., and Atkinson, M. (2011) 
medRxiv preprint doi: https://doi.org/10.1101/2020.04.15.20066647; this version posted April 18, 2020. The copyright holder for this preprint

(which was not certified by peer review) is the author/funder, who has granted medRxiv a license to display the preprint in perpetuity.

All rights reserved. No reuse allowed without permission.

Reduced serum vitamin D-binding protein levels are associated with type 1 diabetes. Diabetes 60, 2566-2570

92. Bolland, M. J., Grey, A. B., Ames, R. W., Horne, A. M., Mason, B. H., Wattie, D. J., Gamble, G. D., Bouillon, R., and Reid, I. R. (2007) Age-, gender-, and weight-related effects on levels of 25 -hydroxyvitamin $\mathrm{D}$ are not mediated by vitamin $\mathrm{D}$ binding protein. Clinical endocrinology 67, 259-264

93. Wang, J., Ohno-Matsui, K., Yoshida, T., Kojima, A., Shimada, N., Nakahama, K., Safranova, O., Iwata, N., Saido, T. C., Mochizuki, M., and Morita, I. (2008) Altered function of factor I caused by amyloid beta: implication for pathogenesis of age-related macular degeneration from Drusen. Journal of immunology 181, 712-720

94. Abdi, H. (2007) The Bonferonni and Šidák Corrections for Multiple Comparisons., Thousand Oaks (CA): Sage.

95. Unlu, M., Morgan, M. E., and Minden, J. S. (1997) Difference gel electrophoresis: a single gel method for detecting changes in protein extracts. Electrophoresis 18, 20712077 
medRxiv preprint doi: https://doi.org/10.1101/2020.04.15.20066647; this version posted April 18, 2020. The copyright holder for this preprint (which was not certified by peer review) is the author/funder, who has granted medRxiv a license to display the preprint in perpetuity.

All rights reserved. No reuse allowed without permission.

\section{Figure 1.}

Experimental Work Flow

1. Pool EDTA Plasma
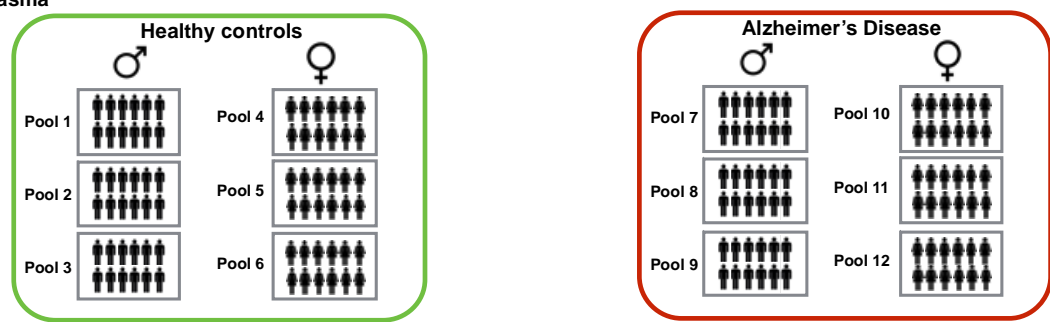

2. Pooled plasma depleted with MARS 14

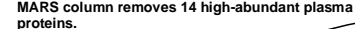

3. HPLC

$$
\begin{aligned}
& \text { MARS col } \\
& \text { proteins. }
\end{aligned}
$$

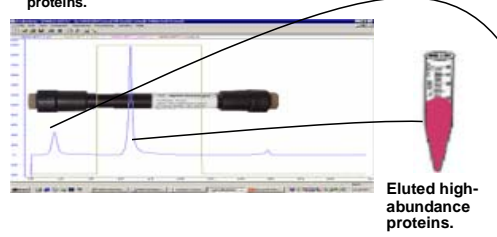

proteins $80^{\circ} \mathrm{C}$
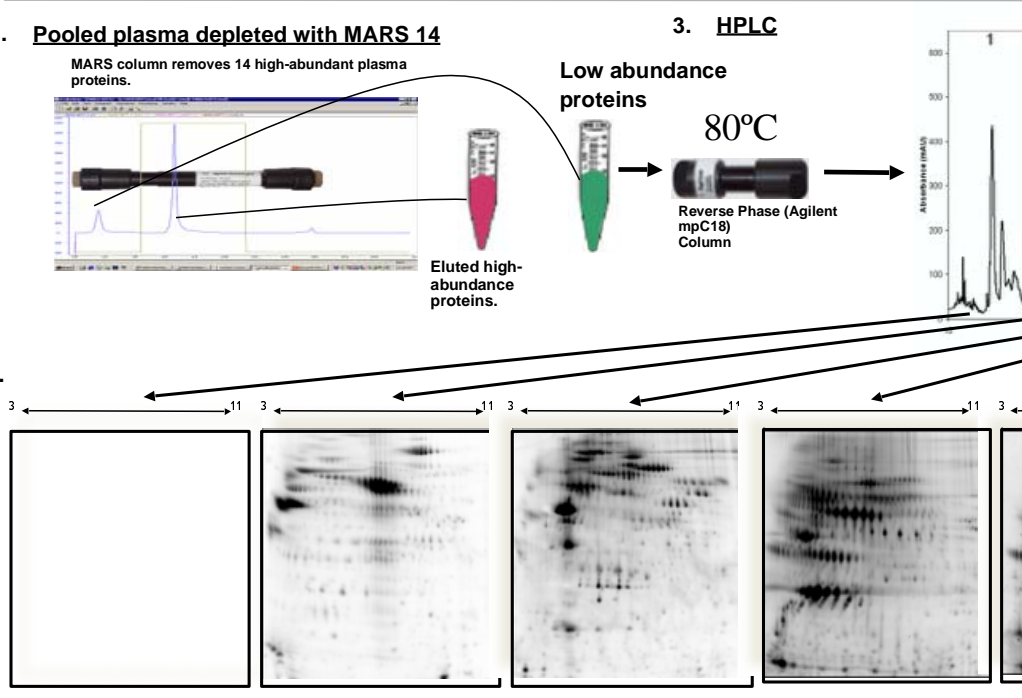

RP Fraction $1 \sim 555$ spots

RP Fraction $2 \sim 580$ spots
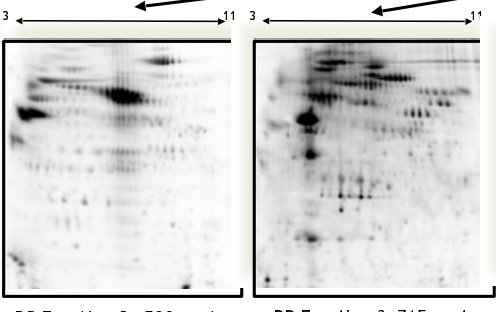

RP Fraction 3 715 spots

RP Fration

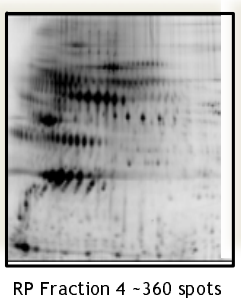

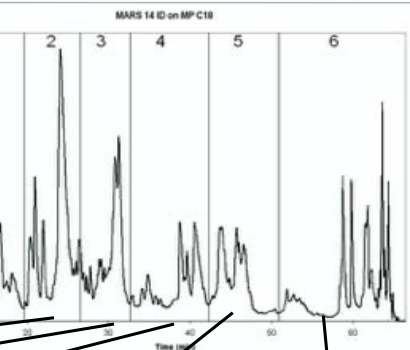
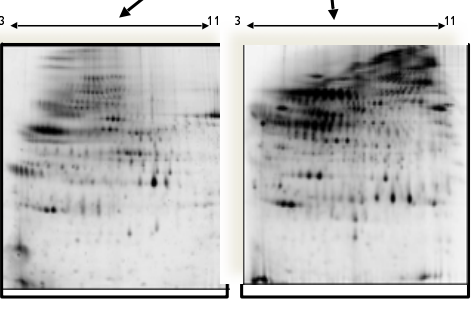

RP Fraction 670 spots RP Fraction $6 \sim 890$ spots 
medRxiv preprint doi: https://doi.org/10.1101/2020.04.15.20066647; this version posted April 18, 2020. The copyright holder for this preprint (which was not certified by peer review) is the author/funder, who has granted medRxiv a license to display the preprint in perpetuity.

All rights reserved. No reuse allowed without permission.

2 Figure 2.

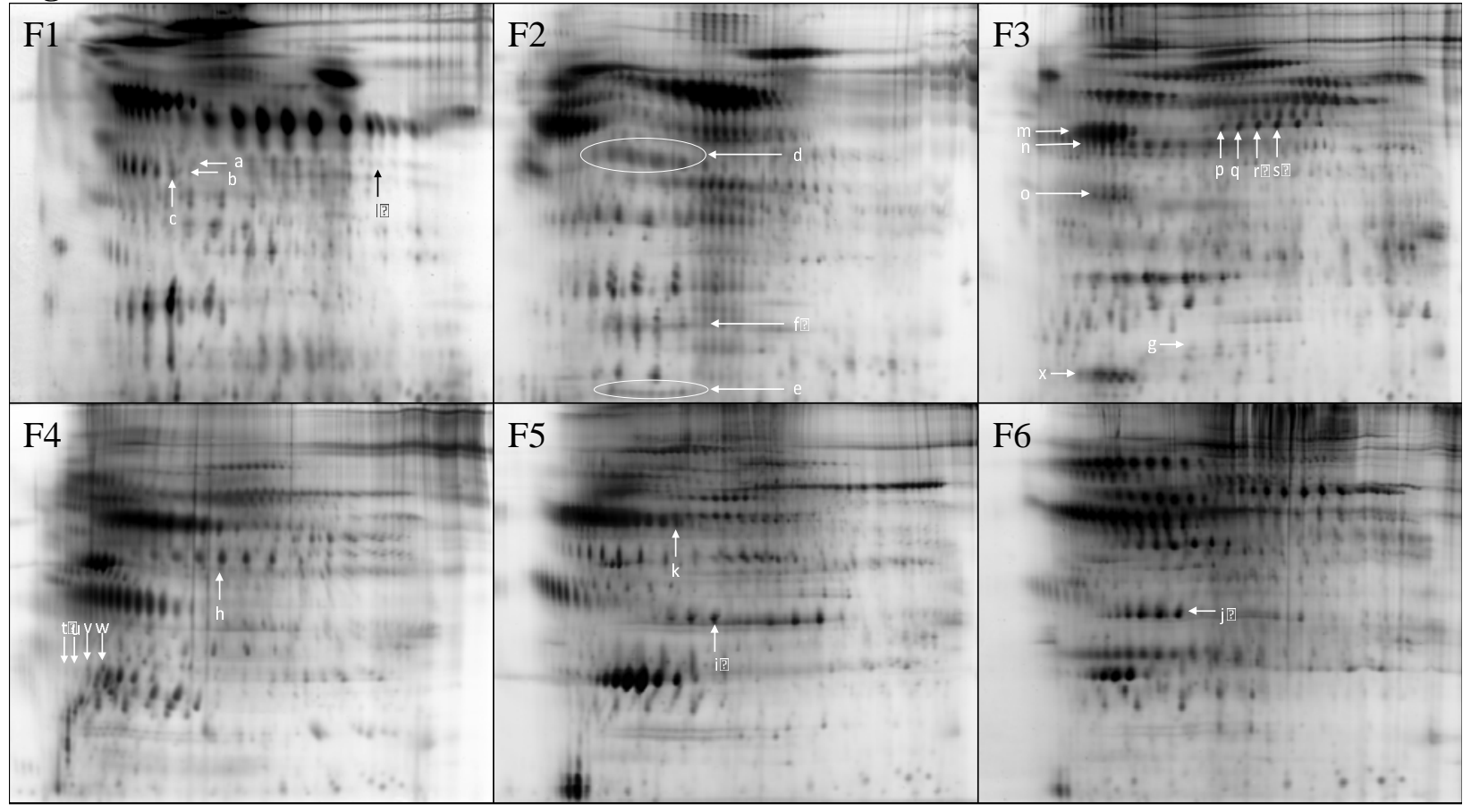

3

4 
medRxiv preprint doi: https://doi.org/10.1101/2020.04.15.20066647; this version posted April 18, 2020. The copyright holder for this preprint (which was not certified by peer review) is the author/funder, who has granted medRxiv a license to display the preprint in perpetuity.

All rights reserved. No reuse allowed without permission.

Figure 3.
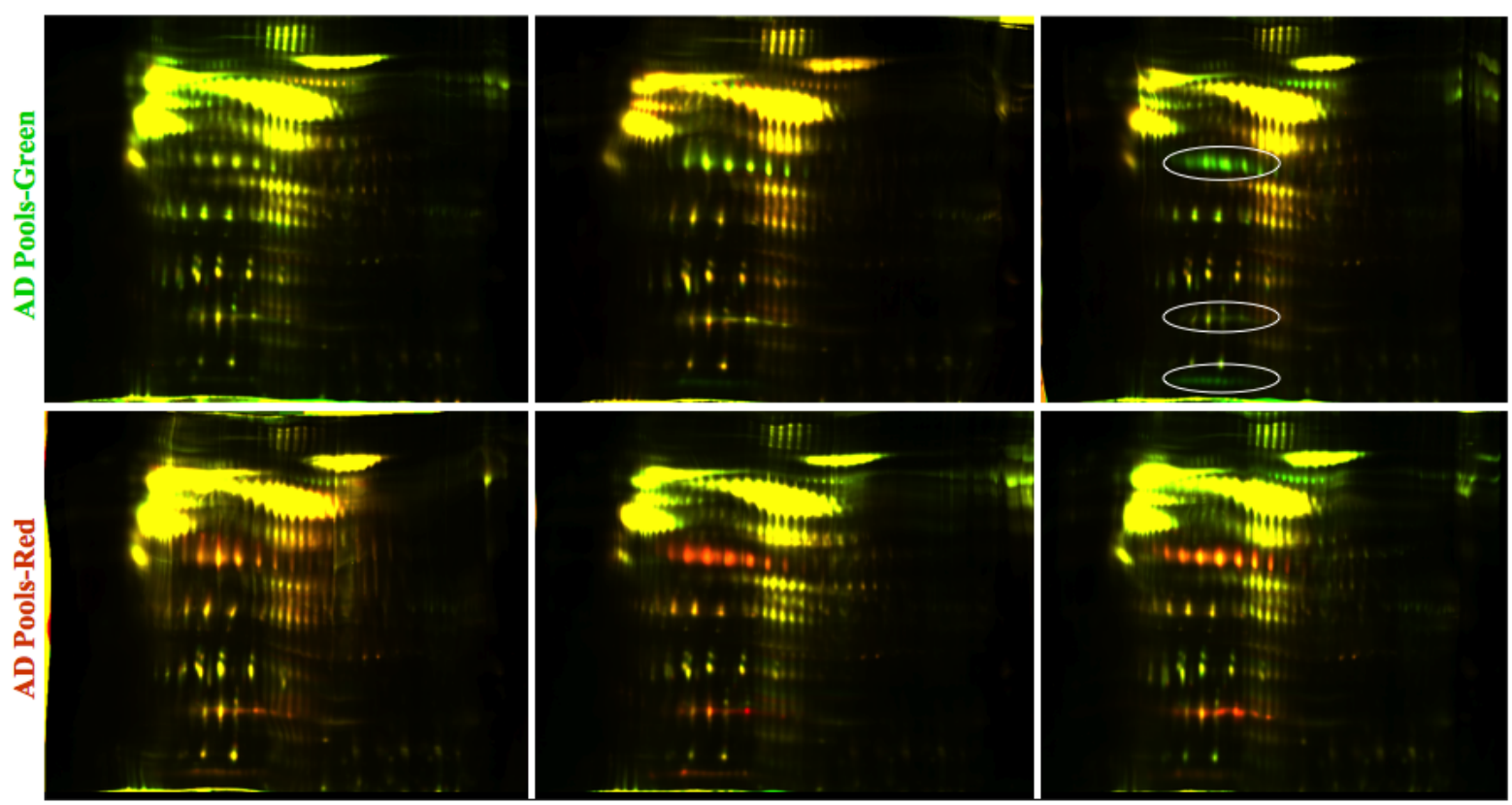
medRxiv preprint doi: https://doi.org/10.1101/2020.04.15.20066647; this version posted April 18, 2020. The copyright holder for this preprint (which was not certified by peer review) is the author/funder, who has granted medRxiv a license to display the preprint in perpetuity.

All rights reserved. No reuse allowed without permission. 
medRxiv preprint doi: https://doi.org/10.1101/2020.04.15.20066647; this version posted April 18, 2020. The copyright holder for this preprint (which was not certified by peer review) is the author/funder, who has granted medRxiv a license to display the preprint in perpetuity.

All rights reserved. No reuse allowed without permission.

\section{Figure 4.}

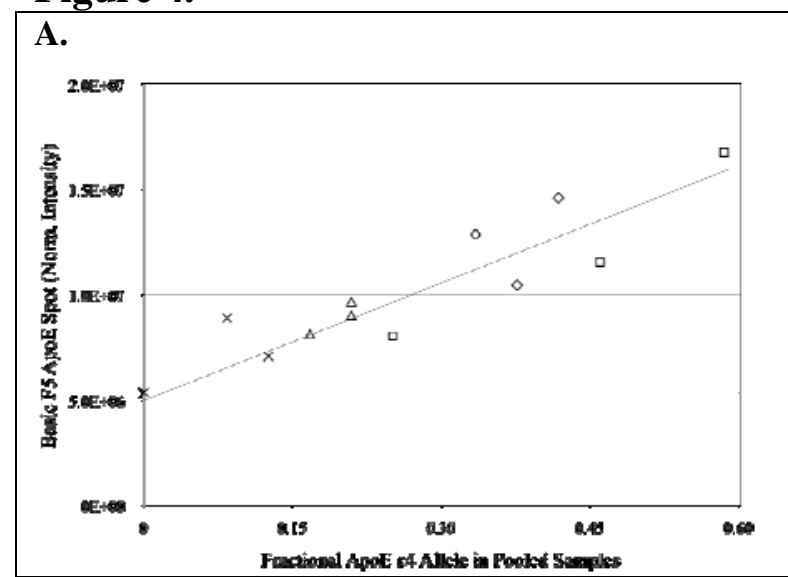

\section{B.}

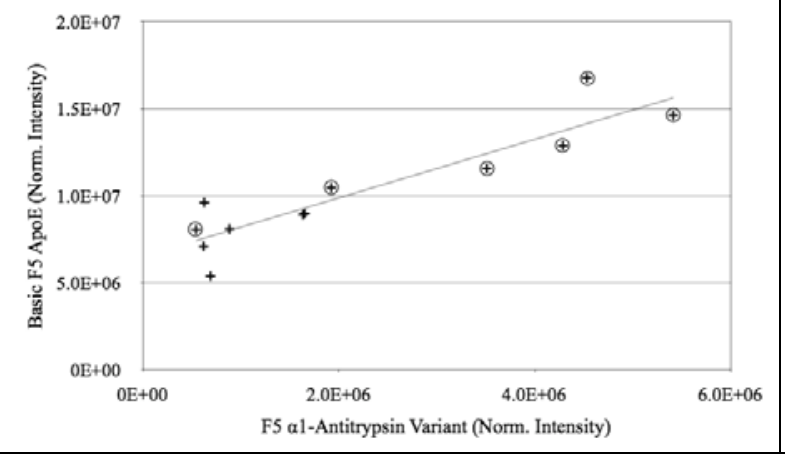

D.

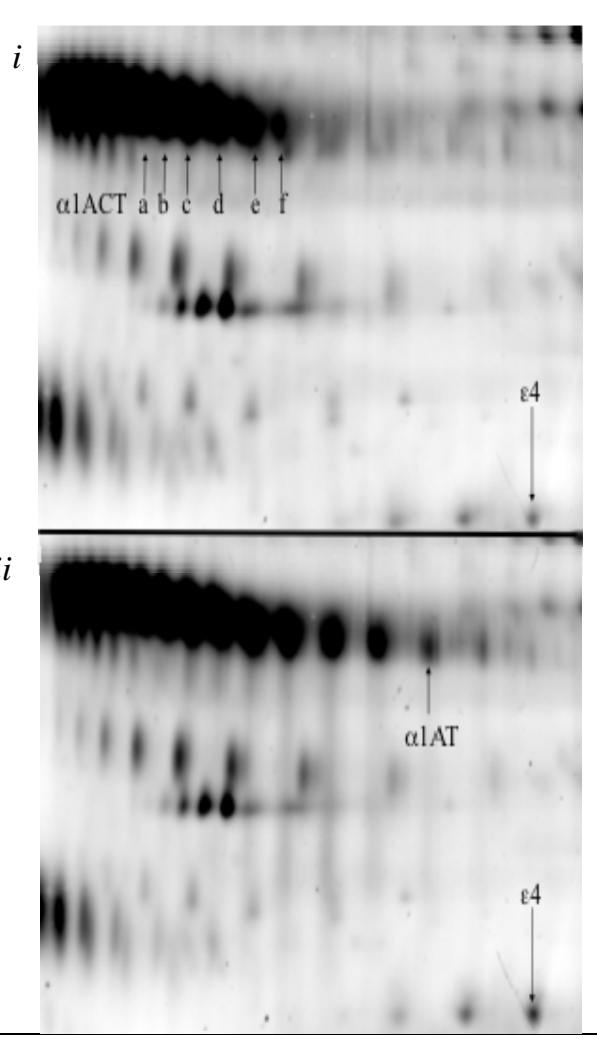

C.
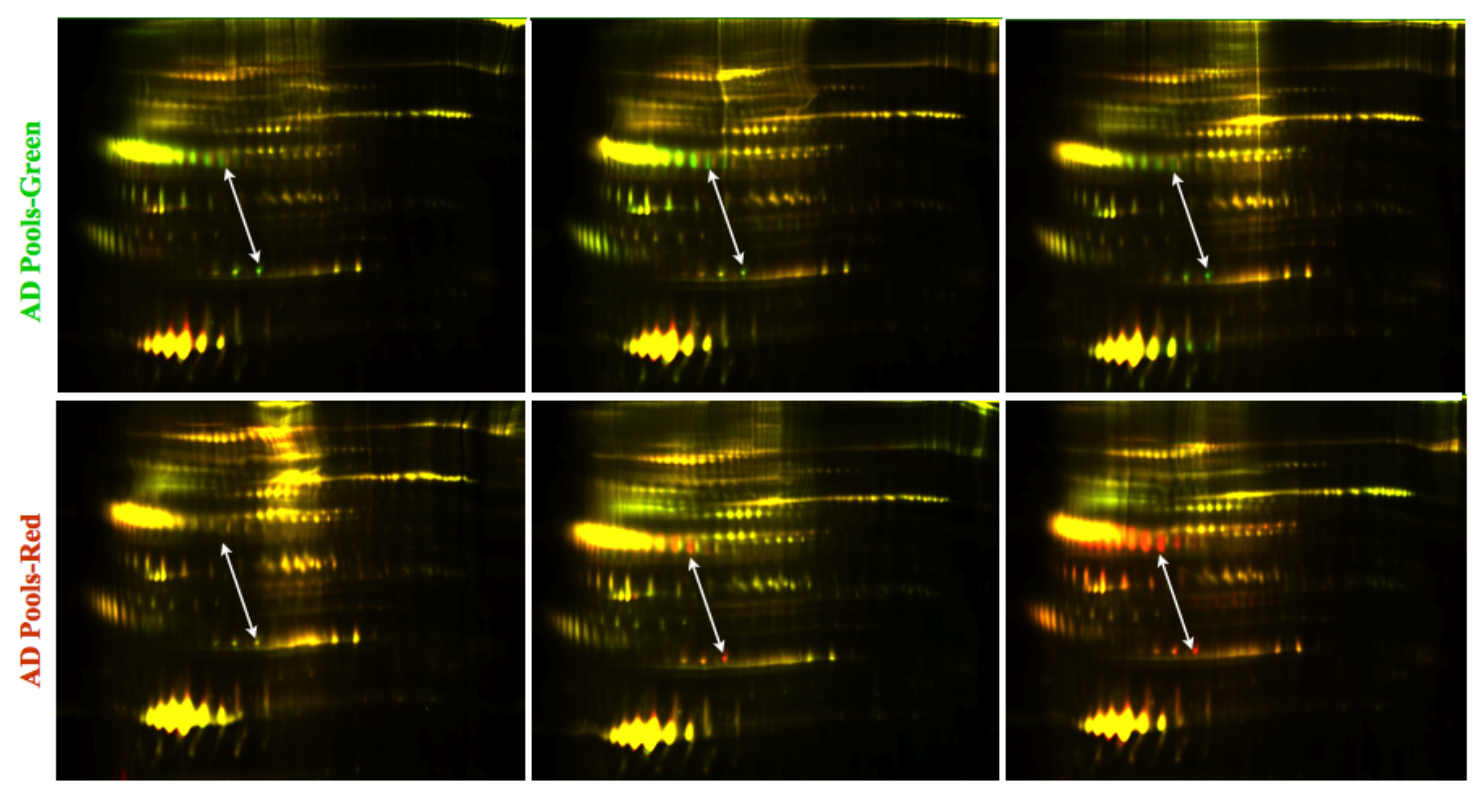
medRxiv preprint doi: https://doi.org/10.1101/2020.04.15.20066647; this version posted April 18, 2020. The copyright holder for this preprint (which was not certified by peer review) is the author/funder, who has granted medRxiv a license to display the preprint in perpetuity.

All rights reserved. No reuse allowed without permission.

Figure 5.

A.

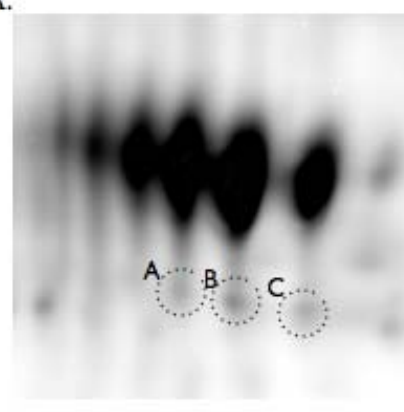

B.

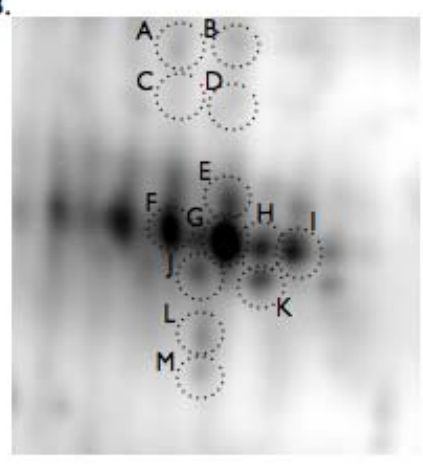

C.

\begin{tabular}{|c|c|c|c|c|c|c|}
\hline A & 2.6 up in FAD & 0.0164 & 2.5 down in MAD & 0.0261 & na & na \\
\hline B & 2.1 up in FAD & 0.0148 & 2.4 down in MAD & 0.009 & 52 & $4 / 8$ \\
\hline C & 2.7 up in FAD & 0.013 & 2.9 down in MAD & 0.00821 & 36 & $3 / 5$ \\
\hline D & 2.3 up in FAD & 0.0145 & 2.5 down in MAD & 0.00822 & 36 & $2 / 3$ \\
\hline E & 1.8 up in FAD & 0.076 & 2.0 down in MAD & 0.00965 & 150 & $7 / 18$ \\
\hline F & 2.2 up in FAD & 0.063 & 2.3 down in MAD & 0.0661 & 279 & $8 / 22$ \\
\hline G & 2.0 up in FAD & 0.0411 & 2.2 down in MAD & 0.0444 & 240 & $7 / 15$ \\
\hline H & 2.4 up in FAD & 0.042 & 2.4 down in MAD & 0.0415 & 178 & $8 / 21$ \\
\hline I & 2.0 up in FAD & 0.0228 & 1.5 down in MAD & 0.272 & 173 & $7 / 18$ \\
\hline J & 2.1 up in FAD & 0.0302 & 2.4 down in MAD & 0.00899 & 196 & $5 / 13$ \\
\hline K & 2.1 up in FAD & 0.0311 & 2.3 down in MAD & 0.0318 & 261 & $7 / 18$ \\
\hline L & 2.1 up in FAD & 0.0289 & 2.3 down in MAD & 0.0169 & 79 & $5 / 13$ \\
\hline M & 2.0 up in FAD & 0.0228 & 1.5 down in MAD & 0.272 & 93 & $6 / 15$ \\
\hline
\end{tabular}

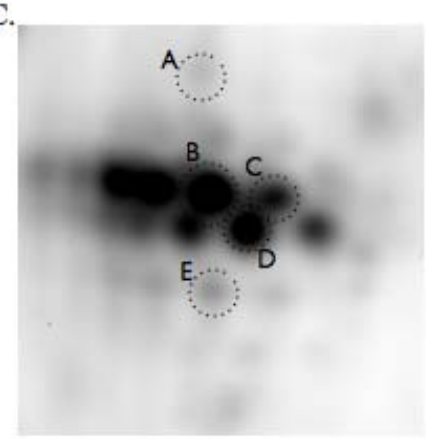

\begin{tabular}{|c|c|c|c|c|c|c|}
\hline ID & Female Fold Change & p-value & Male Fold Change & p-value & Mascot & \# pep/cover\% \\
\hline A & 2.4 up in FAD & 0.0004 & 2.6 down in MAD & 0.269 & 356 & $11 / 29$ \\
\hline B & 2.3 up in FAD & 0.0015 & 2.5 down in MAD & 0.00694 & 287 & $11 / 20$ \\
\hline C & 1.5 up in FAD & 0.0499 & 1.5 down in MAD & 0.15 & 325 & $9 / 25$ \\
\hline
\end{tabular}

\begin{tabular}{|c|c|c|c|c|c|c|}
\hline A & 1.8 up in FAD & 0.0064 & 1.9 down in MAD & 0.0475 & 38 & $2 / 6$ \\
\hline B & 1.6 up in FAD & 0.00155 & 1.7 down in MAD & 0.0466 & 108 & $4 / 8$ \\
\hline C & 1.5 up in FAD & 0.0108 & 1.4 down in MAD & 0.253 & 62 & $3 / 6$ \\
\hline D & 1.7 up in FAD & 0.00142 & 1.8 down in MAD & 0.0401 & 240 & $7 / 15$ \\
\hline E & 1.9 up in FAD & 0.00358 & 1.9 down in MAD & 0.0122 & na & na \\
\hline
\end{tabular}



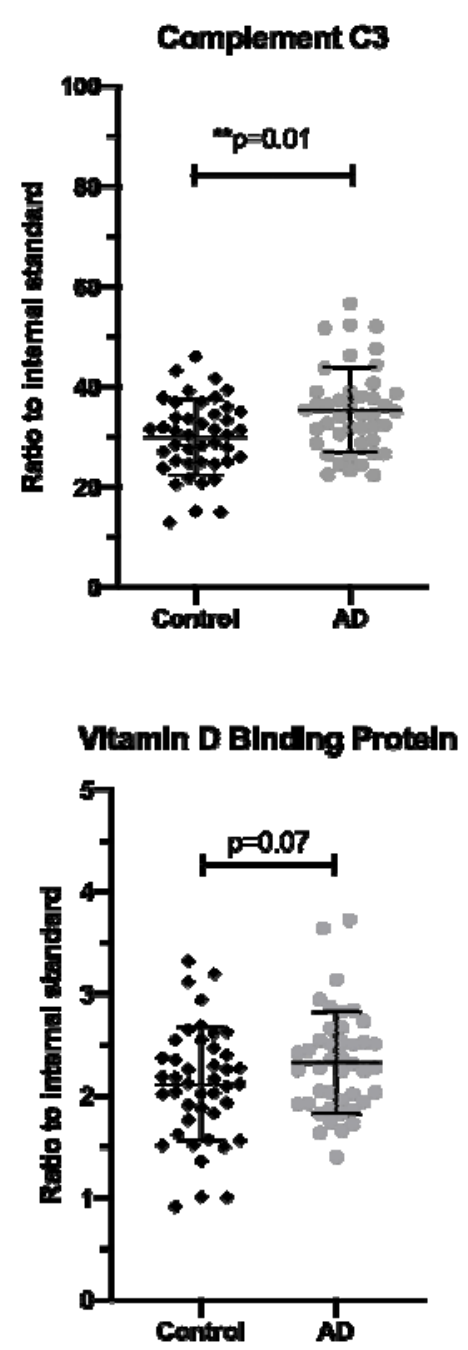

Histidine rich glycoprotein

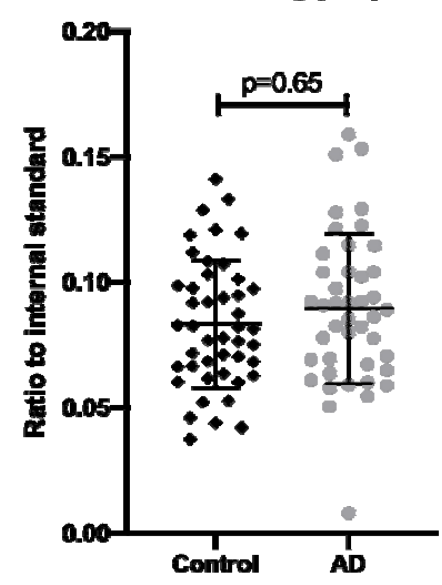

Beta-2-Hicroglobulin

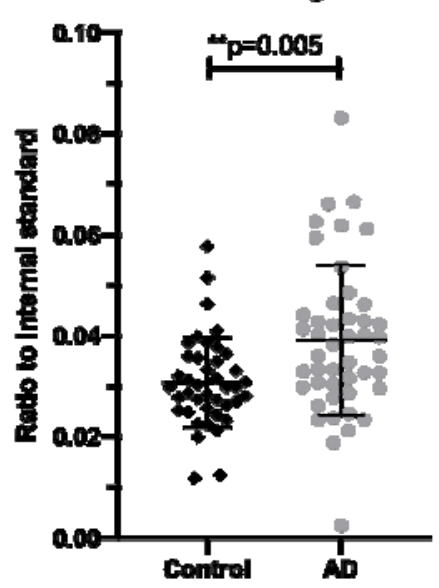

Znc alpha ghycoprotein

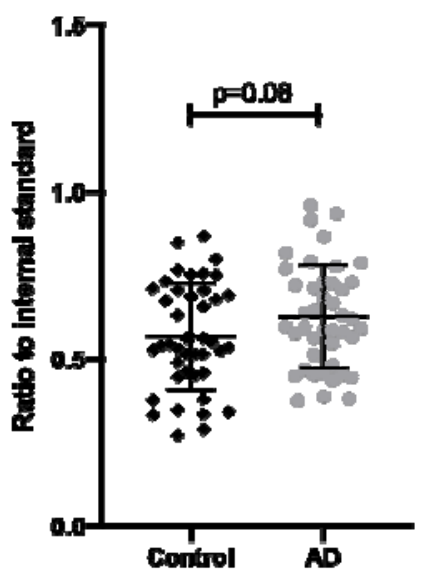

Creactive protein

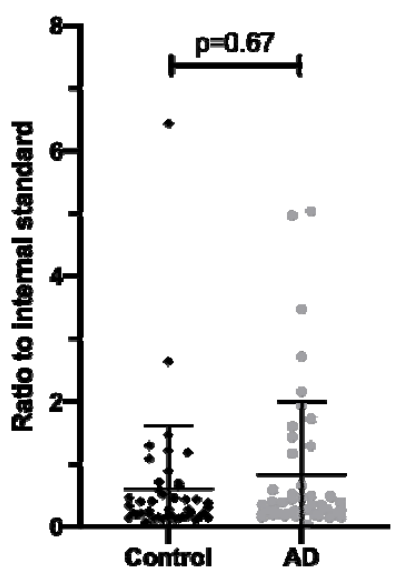

Perroxiredoxin-2

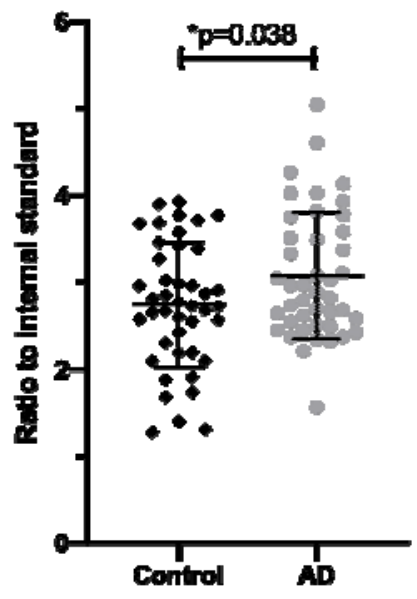

Haptoglobln

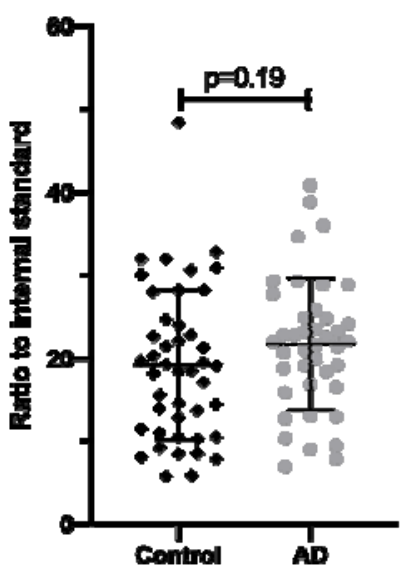

Âpha-í-antitrypsin

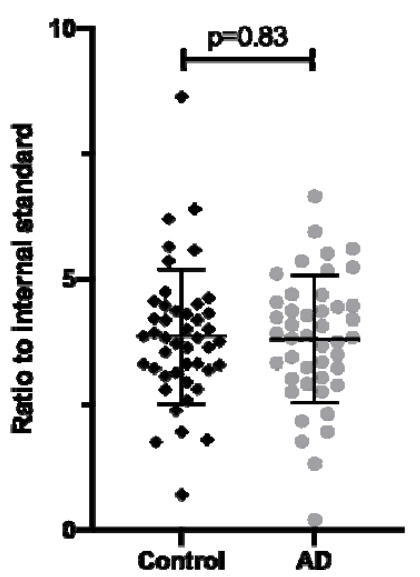


medRxiv preprint doi: https://doi.org/10.1101/2020.04.15.20066647; this version posted April 18, 2020. The copyright holder for this preprint (which was not certified by peer review) is the author/funder, who has granted medRxiv a license to display the preprint in perpetuity. 